\title{
El derecho en el Egipto faraónico
}

\author{
FÉLIX ALONSO * Y ROYANO **
}

\begin{abstract}
RESUMEN
El presente trabajo es una síntesis del conocimiento actual sobre la ley en el

Egipto faraónico, incluyendo los derechos de familia y dentro de éste, el derecho matrimonial, una materia bien conocida por el autor.

Una pequeña parte resumida fue preparada para una conferencia en la

Universidad "Rafael Landívar" de Guatemala, que no fue posible disertar debido a que el autor fue atracado a su llegada a aquel país. El derecho faraónico es una materia no muy conocida; algunos autores como

Revillout, Pirenne, Théodoridés,

Kruchten, Valbelle y otros, se han dedicado a ello. Pero aquí en España es prácticamente desconocida la materia y no discutida por nuestros especialistas. Sobre Alonso y Royano el egiptólogo armenio Arpag Mekhitarian dijo: «Los autores

\section{ABSTRACT}

This present work is a syntesis of the actual knnowledge about law in the pharaonic Egypt, included family rights, and within it, matrimony law, a matter known extremely well to the author.

$A$ very small summarized part was not possible to give due to the fact that the author was robbed at his arrival to this country.

The pharaonic law is a matter not very known; some authors like Revillout, Pirenne, Theodorides, Kruchten, Valbelle and others, have been dedicated to it, but here in Spain this is practically an unknown matter and not discussed by our specialists. About De Alonso and and Royano the Armenian borned egyptologist Arpag Mekhitarian said: "The Spanish authors dealing with the Ancient Egypt, and specially about pharaonic law, are very special:
\end{abstract}

* Doctor en Derecho. Miembro de la Fondation Egyptológique. Reine Elisabeth. Bruxelles.

** Profesor-Tutor de Historia del Derecho de la UNED, en el C.A. “Bizkaia". 
españoles que tratan sobre el Antiguo

Egipto, y especialmente sobre el derecho faraónico son rarísimos, tenemos aquí el trabajo de un pionero". Actualmente, el autor está preparando un volumen ampliado sobre el derecho faraónico que, esperamos, sea de gran interés.

\section{DEDICATORIA}

Este trabajo está dedicado a la profesora la doctora Pilar Fernández Uriel, como prueba de mi profunda amistad hacia ella y su conocimiento de la antigua Grecia. we here have the work of a forwarded".

In this moment the author is preparing an extended volume abbout the pharaonic law that we hope you find of great interest.

\section{DEDICATORY}

This work is dedicated to my teacher Doctor Pilar Fernández Uriel, as proof of my deepest friendship towards her and her knowledge about the Ancient Greece.

\section{UNA APROXIMACIÓN AL DERECHO EN EL EGIPTO FARAÓNICO}

\section{Primera Parte}

\section{a) Generalidades}

Hemos descubierto que, si explicar conceptualmente el «ius", la «iustitia" y la «lex", es de una dificultad casi suprema, cuando no insuperable, debido a la carga de subjetividad ontológica, en su expresión aristotélica y sentido wolffiano, además de su convencional interpretación, esa dificultad se complementa cuando los historiadores del derecho antiguo nos encontramos con la participación temporal de la historia, o con el tiempo-eje como lo llama Jarpers, donde en muchas ocasiones ya sólo quedan vestigios, apariencias, y ruinosas certidumbres. De tal suerte que, para sumar dificultades, nos vemos obligados a apoyarnos en la filología, la arqueología, la onomástica, la literatura, el arte, la religión y, tantas y tantas, otras ciencias, afines unas, dispares otras, que hace de todo ello que nuestras certezas de hoy, sean incertidumbres de mañana y estrepitosos errores con el transcurrir del tiempo.

Por eso, en el historiador del derecho antiguo toda cautela es poca, y todo dato se torna en dubitación, hasta el extremo de cuando se nos escucha, se tiene la cuasicerteza de estar ante despistados sabios atiborrados 
de datos, nada contundentes en sus afirmaciones, cuando no se enzarzan en estériles e inútiles discusiones doctrinales que a nada conllevan y que, ciertamente nada resuelven.

Pero esto tampoco debe extrañarnos, dado el polvo y ruina entre los que nos movemos. Si añadimos a todo ello las desapariciones, interpolaciones, reinterpretaciones y ocultaciones interesadas con fines sociales, políticos, religiosos, económicos y jurídicos, entre otros más, de escuelas, grupos y doctrinas, caeremos en la cuenta de que todo lo que sabemos de la historia del derecho antiguo es poco, y está sujeto a permanente discusión y revisión.

Tal es el caso, como no podía ser menos, del derecho egipcio faraónico que trataremos aquí de comentar con las necesarias cortedades de mi conocimiento investigador y científico.

Una última advertencia es necesario hacer ahora: Yo no soy un arqueólogo, ni un filólogo, ni un historiador general. Soy simple y exclusivamente un jurista, y dentro de ese campo, un historiador del derecho antiguo, con especial dedicación al derecho faraónico y fundamentalmente al derecho de familia. No puedo, por tanto, entrar en vorágines discusivas que tanto gustan a las escuelas, sobre si la Historia del Derecho es una ciencia jurídica o una ciencia histórica, al estilo de García Gallo o Tomás y Valiente, o si se trata de una ciencia "dual», como preconiza Font Rius o su discípulo Lalinde, en España. La Historia del Derecho pertenece sin más, a la "enciclopedia de la ciencia».

$Y$ dicho esto vamos a entrar en la materia que nos interesa sobre:

b) La justicia y su aplicación a través del Derecho:

Los egipcios llamaban a su tierra "Kmt" (Kemit), es decir «negro» 0 "la negra", y tenían razón, dado el lodo que recubría el fondo del Valle nilóti$\mathrm{co}$, cuando al retirarse las aguas de las crecidas, dejaban un color oscuro, que contrastaba fuertemente con el blanco-amarillento de las arenas desérticas cercanas.

También usaban un nombre dual: «T3.wï» (Tayui), es decir «los dos países» o «el doble país», probablemente con posterioridad al comienzo del fenómeno unificatorio histórico iniciado por el rey Escorpión y concluído por Narmer o Menes, que en todo esto sólo hay conjeturas, por el gran desconocimiento existente ante la falta de documentos.

La Biblia utiliza varios vocablos para designar a Egipto, o mejor dicho algunas zonas de Egipto. Por ejemplo cuando cita el «País de Cam», 
puesto que el nombre "Cam" es precisamente el segundo hijo de Noé, un ancestro epónimo, padre de toda una serie de pueblos, incluidos los egipcios.

Además, como dice Diop, Cam o Kem, en hebreo significa «calor», "negro", "quemado». En Génesis, X,6 se dice: "Hijos de Cam fueron: Kush, Misraim, Fut y Canaán». Aquí podría aplicarse la teoría de Obenga y de Diop, ilustres científicos africanos y africanistas, sobre la original negritud de los egipcios, y que, con posterioridad, han seguido con entusiasmo los profesores Martín Bernal, en Estados Unidos, y mi ilustre amigo Ferrán Iniesta Vernet en Barcelona, y que parece definitivamente admitida después de la discusión científica habida en el Coloquio de la Unesco de 1974 en El Cairo, respecto al significado de una civilización negro-africana en contraposición a la teoría de la influencia de una raza blanca, semita, sobre la civilización griega. Personalmente estoy de acuerdo con la teoría del origen africanista y negro para la civilización egipcia, de Bernal e Iniesta.

De ahí que a los habitantes del Alto Egipto, la Biblia los llame "Pathrusim» (Pazrusim). El vocablo parece derivar del egipcio «p3t3 r'sï» (pata resi), o «tierra del sur». Lo citan así, junto a la palabra «Misrayim», a la que dan el mismo sentido Isaías y Jeremías. Lo que ocurre es que en la Biblia, éste último término aparece 680 veces con terminación dual, es decir, designando a Egipto entero, y cuya raíz podría significar «tierra fortificada», como una derivación de la palabra hebrea «Mâsor» o «fortificación».

El nombre con el que, actualmente, conocemos a Egipto proviene, como no podía ser menos, del latín "Aegyptus" y cuyo origen está en el griego (Aígiptós), que era como transcribian los griegos el egipcio «Hwk3-pth» (gu ka pta), es decir, «la fortaleza del ka de Path», nombre con el que se designaba al templo de Menfis, y cuya nominación se dió después a todo Egipto. No hay más que recordar que los griegos, desde el advenimiento de Psamético I, en la XXVI dinastía, estaban en Egipto creando emporios comerciales primero, y creando colonias y cuerpos del ejército egipcio después, hasta conformar desde el 333 a.C. el período greco-egipcio o ptolemaico. La mutua influencia desde entonces, es innegable.

De modo que, como decía antes, se pueden apreciar las dificultades con que nos tropezamos los investigadores, simplemente para asignar un nombre al pueblo antiguo que nos viene ocupando. Otro tanto podemos decir del vocablo «faraón», como transcripción griega del egipcio «Pr 3ç» (Per-aa) o «la gran casa», llamado en hebrero «faraón», y que 
más tarde como nombre genérico, recibió el de «furón» o «Ferón» en copto antiguo, y que yo siempre sustituyo por Horus, ya que éste era en definitiva uno de los 5 títulos oficiales con el que había que dirigirse a su persona.

Quizás idénticas dificultades se nos planteen en los vocablos con que los egipcios parecían querer designar los conceptos que tenemos nosotros de "derecho", «justicia", "ley» y "norma». Pero no cabe duda de que la aplicación del derecho, la interpretación de la norma y la solicitud de justicia estaba, en la práctica diaria de ese pueblo, en lo que tenemos constancia histórica, efectuándose desde tiempos inmemoriales.

Por otro lado coincidirán conmigo en que todas las comunidades tienen normas, sean consuetudinarias o escritas. Normas que tienden un puente hacia la consecución de la justicia, de «aquello que es», o que la comunidad considera que "es lo justo". Tales normas de conducta uniformes, definen modelos o "leyes», conforme al derecho que esas comunidades pretenden para sí, considerándolas formulaciones del pensamiento religioso primero, moral o filosófico después, y con un fuerte componente evolutivo de praxis social por último, a través del tiempo y del espacio. Como Vds. saben, la fenomenología del carácter modificable de la justicia, y por tanto del derecho positivo, ha sido formulado en nuestra época por Stammler, pero el fenómeno en sí, naturalmente, existía antes de su formulación en todas las sociedades de la antigüedad.

Los egipcios disponen, desde las primeras dinastías, de «m3çt» (Maat) que es indistintamente "verdad, orden y justicia» y como muy bien dice el profesor Leclant: «en el caos de las fuerzas del desorden, Maat instituye la norma, la mesura en todos los órdenes de la creación, las dos esferas cósmica y social, alineadas en constante correspondencia».

De tal suerte es así, que el egipcio faraónico tenía en "maat» un modelo normativo de conducta a través del equilibrio armónico que impide el dominio del mal, del caos. Por eso cuando el equilibrio se rompe, cuando el armónico se difumina, «Maat» queda oculta y hace su aparición el caos, es decir la injusticia. De ahí que la injusticia social se produce por el desequilibrio entre ambas fuerzas. Este es, en la literatura egipcia, el entramado del cuento de «El campesino elocuente» cuando se queja de la insensibilidad, la inactividad y la codicia humanas, y que nos ha sido conservado en los papiros Berlín 3025, 3032, 10274 y otros más, probablemente de finales de la XII dinastía, es decir hacia 1962 a.C.

Este concepto de precisión y equilibrio, idéntico al que tenemos en la actualidad de la justicia, los egipcios lo manifestaron hasta la saciedad en sus tumbas desde las primeras dinastías. Y como un simple ejemplo 
vamos a ver un pasaje del Libro de los Muertos (ilustración no 1) donde se aprecia el juicio de Osiris, por el que tienen que pasar todos los muertos. Aquí se ve la balanza, que pesa el comportamiento en vida del difunto, sostenida por el dios Anubis, el de cabeza de chacal. En uno de los platillos se coloca, dentro de un vaso canopo, el corazón del muerto, y en el otro a la diosa «Maat», caracterizada por la pluma ceñida en su cabeza, como símbolo de la verdad, cuyo peso eran tan liviano como el de una pluma. Para que el difunto pudiese ser «justificado» y no ser arrastrado a los infiernos del «fuego interior», su corazón no tenía que pesar más que la pluma de "Maat». En esta otra ilustración del Papiro de Ani (ilustración n²) que se encuentra en el Museo Británico, catalogado con el $n^{\circ} 10.470$, se aprecia a la izquierda a Ani y su esposa, dirigiéndose al pesaje de sus acciones y a la derecha al dios Thot, como notario de los dioses, dando fe registral del acto. Detrás se encuentra "Ammit», la devoradora de muertos, a la espera de que por una mala acción en vida del difunto, la balanza se incline.
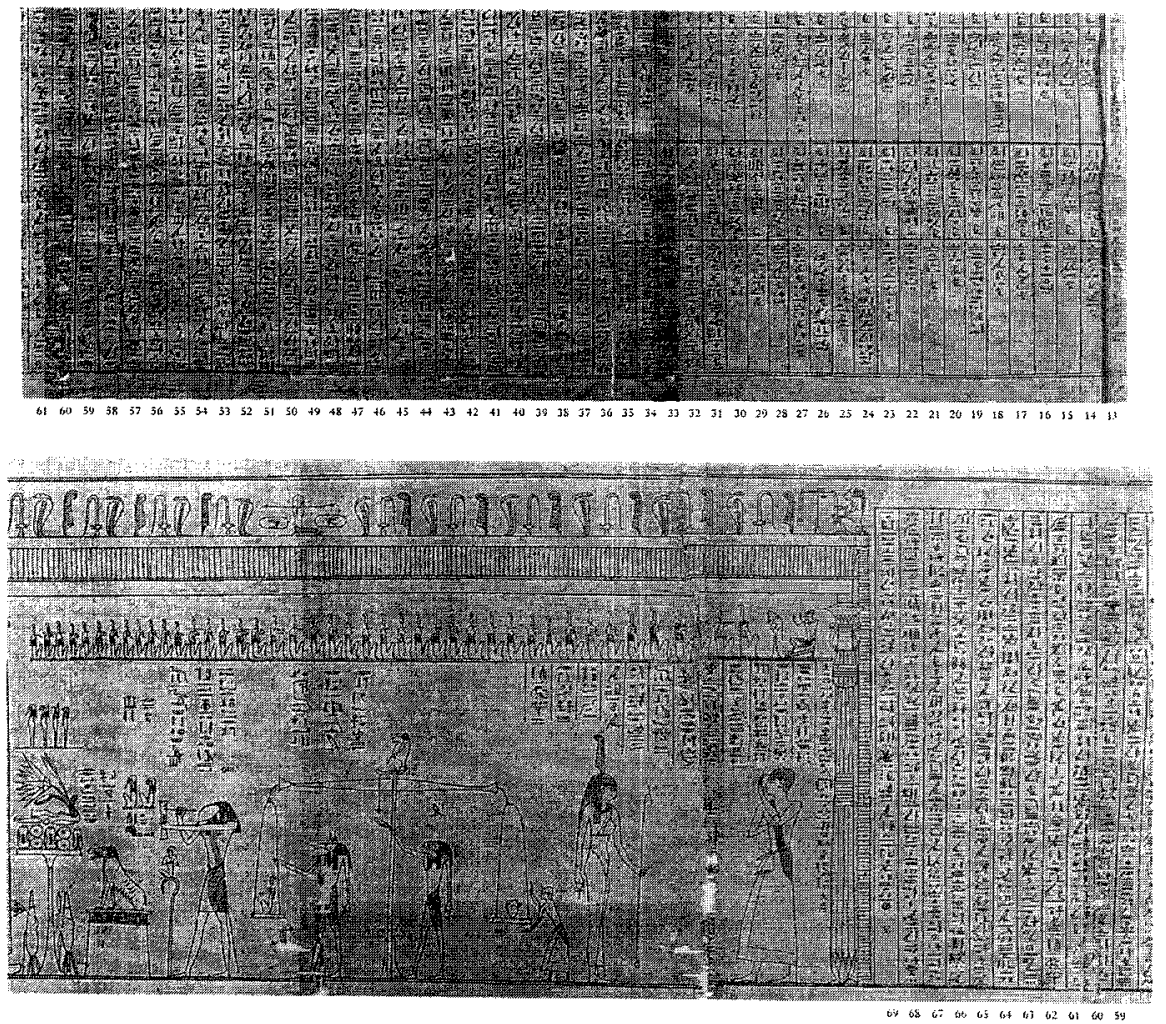

llustración 1. Libro de los muertos. 


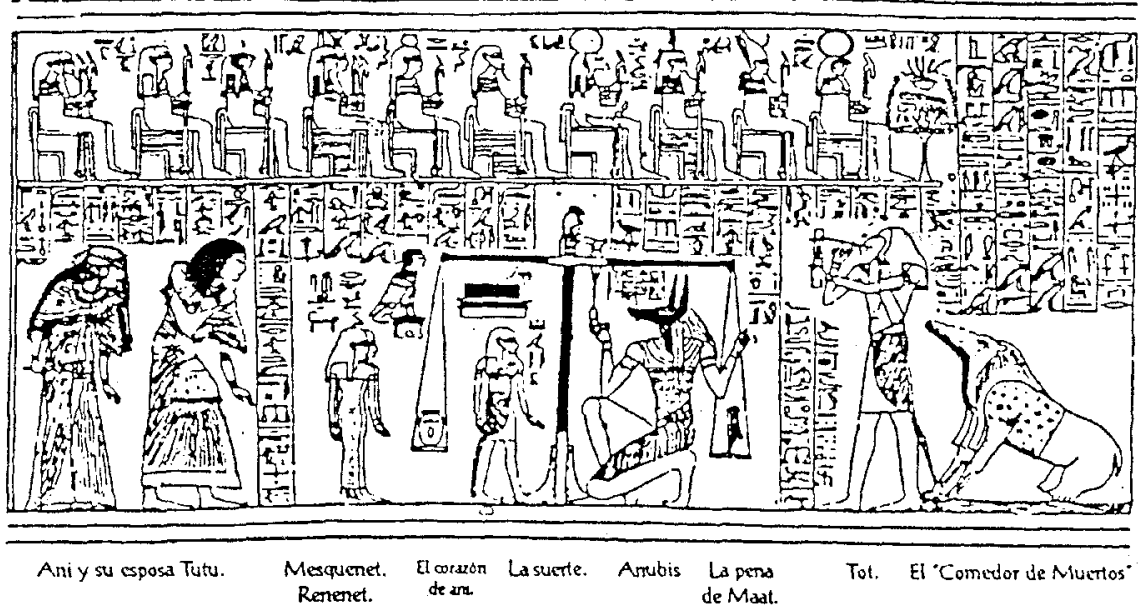

Mustración 2. Papiro de Ani.

Obsérvense las identidades de estas otras dos viñetas, (llustraciones $n^{\circ}$ 3 y 4) una del papiro de «Hunefer» y otra del papiro de «Quena».

Los más optimistas afirman que, desde los tiempos más antiguos y nebulosamente históricos, Menes promulgó una legislación para todo el Egipto, incrementando el mercado extranjero, y habiéndose superado el trueque, el cambio monetal se hacía con metales como el cobre, el oro y la plata, que eran pesados en balanzas.

Los investigadores hemos descubierto que sobre la existencia de leyes, algo parece ser cierto, porque entre otros soportes documentales que han llegado a nosotros, se encuentra la tan conocida estela de Gizeh, descubierta por Steindorff en 1910, cerca del templo de la pirámide de Kheos (Jeos), y datada entre la ! V y $V$ dinastías, es decir, entre el año 2.700 y el 2.400 a.C., que se puede ver en el museo de El Cairo, y que es uno de los documentos jurídicos más antiguos de la humanidad, pues se trata de la compraventa de una casa, en la villa de «Khwït Khwfw» (Juit Jufu). El vendedor es el escriba «Tnt» (Tenti), y el comprador el sacerdote "Km3pw» (Kemapu), que paga al vendedor el equivalente a 10 «sh3ït» (Chait). Ese pago equivalente fue un mueble hecho con madera de anís, otro con madera de sicomoro, y una cama hecha con madera de cedro. Observen Vds. este maravilloso documento (ilustracción $n^{0} 5$ ). En esta parte de la estela se encuentra la declaración del comprador que dando su nombre y título sacerdotal dice: "He adquirido esta casa del 


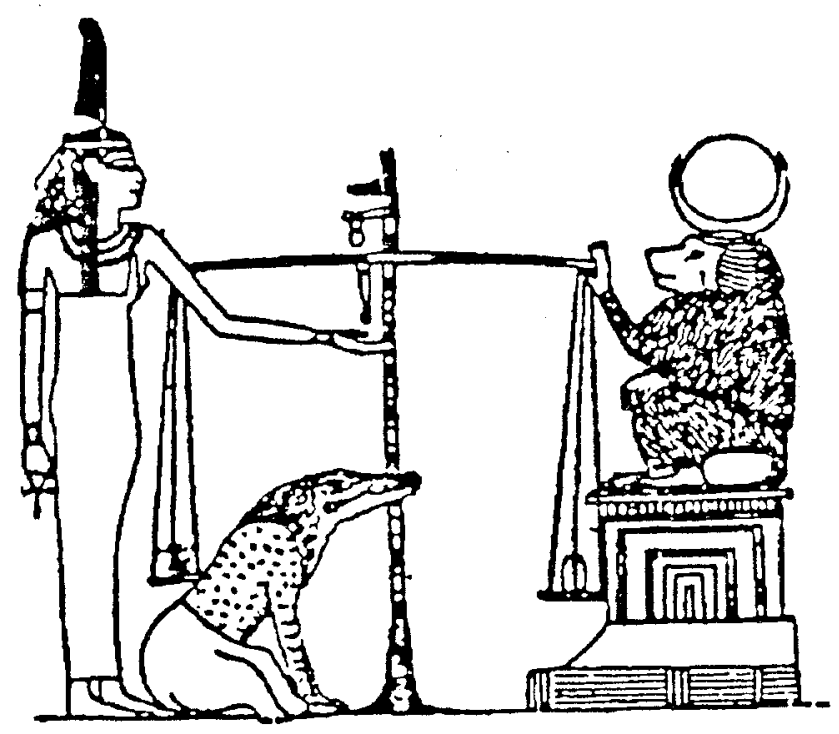

El Pesaje del corazón. (Del Papiro de Quena).

llustración 3.

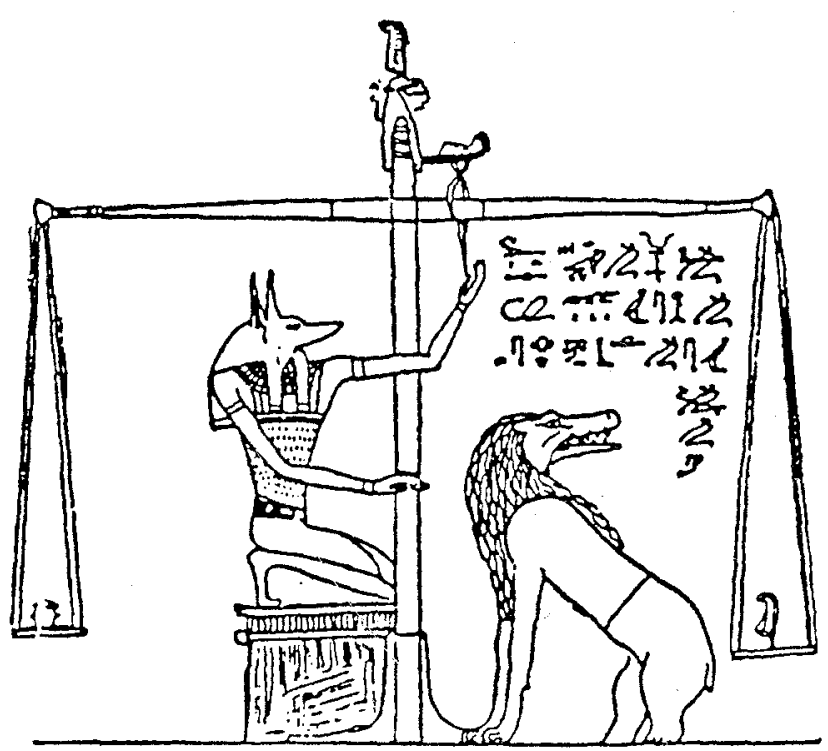

El Pesaje del corazón. (Del Papiro de Hu-Nefer).

Ilustración 4. 


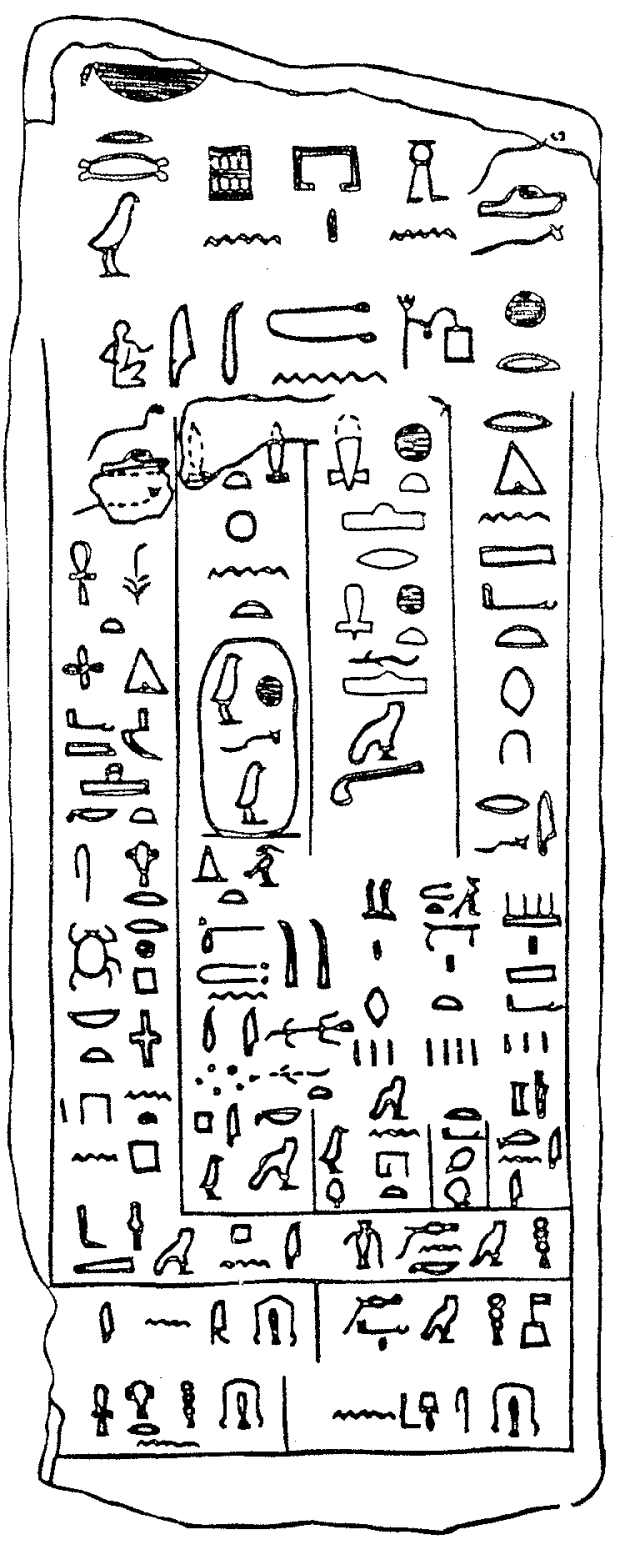

Ilustración 5. Estela de Gizeh descubierta por Steindorff. 
escriba Tenti y he dado por ella 10 chatis». En el lado izquierdo de la estela, y en esta parte, se encuentra la declaración del escriba Tenti como vendedor: "Por la vida del rey que haré que todo se cumpla conforme al derecho, y que resultes satisfecho en este punto, de suerte que todo lo que forma parte de la casa te pertenezca». En esta otra parte se indica, arriba el precio: «1 mueble de madera de anís, 3 chati; otro de madera de sicomoro, 3 chati; y una cama de madera de cedro, 4 chati. $Y$ debajo la descripción de la casa: "Construcción a cordel y con techo de madera de sicomoro". En el centro se encuentran descritas las formalidades de la venta, es decir, "sellado en la casa del sello, ante el consejo local de la pirámide de Jeos, y ante varios testigos" y abajo del todo están las firmas de los testigos asistentes a la compraventa, y que fueron el obrero Meji y los sacerdotes funerarios Sebni, Ini y Nianjor».

A través de éste, y varios contratos de compraventa más, sabemos que el «dinero egipcio» en el Imperio Nuevo era el "dbn" (deben) como unidad de medida o valor de cambio, y que antes en el Imperio Antiguo había sido el "sh3ït» (chait), pero, como se puede apreciar, el trueque comercial de objetos o simple cambio, cuyo contrato en nuestro lenguaje jurídico actual sería la permuta, que se contempla en el artc. 1.538 del C. civil español, cuando dice: "La permuta es un contrato por el cual cada uno de los contratantes se obliga a dar una cosa para recibir otra». Y en parecido sentido se expresa el C. civil guatemalteco, que la contempla en el Título $V$ de la $2 .^{a}$ parte del Libro $V$, cuyo artc. 1.852 dice expresamente: «La permuta es un contrato por el cual cada uno de los contratantes transmite la propiedad de una cosa a cambio de la propiedad de otra. Cada permutante es vendedor de la cosa que da y comprador de la que recibe a cambio; y cada una de las cosas es precio de la otra. Este contrato se rige por los mismos principios del contrato de compraventa, en lo que fueren aplicables».

Lo mismo podemos decir del Code civil francés que en su Título VII, del Libro III, en el artc. 1.702 expresa: «La permuta es un contrato por el cual las partes se entregan respectivamente una cosa por otra».

$Y$ el Code civil belga, en un mismo título, libro y artículo, dice idénticamente lo mismo. Fácil es comprobar cómo el concepto jurídico de la compraventa, aunque no se conociese la moneda, se efectuaba a través del cambio o permuta, desde las más aritiguas dinastías egipcias, quiero decir desde los más antiguos tiempos.

No sólo las fuentes documentales epigráficas y arqueológicas son las que lo confirman, sino que vienen a reforzarlas las historiográficas. Así, Herodoto, en el Libro II, dedicado a Euterpe, de "Los nueve libros de la 


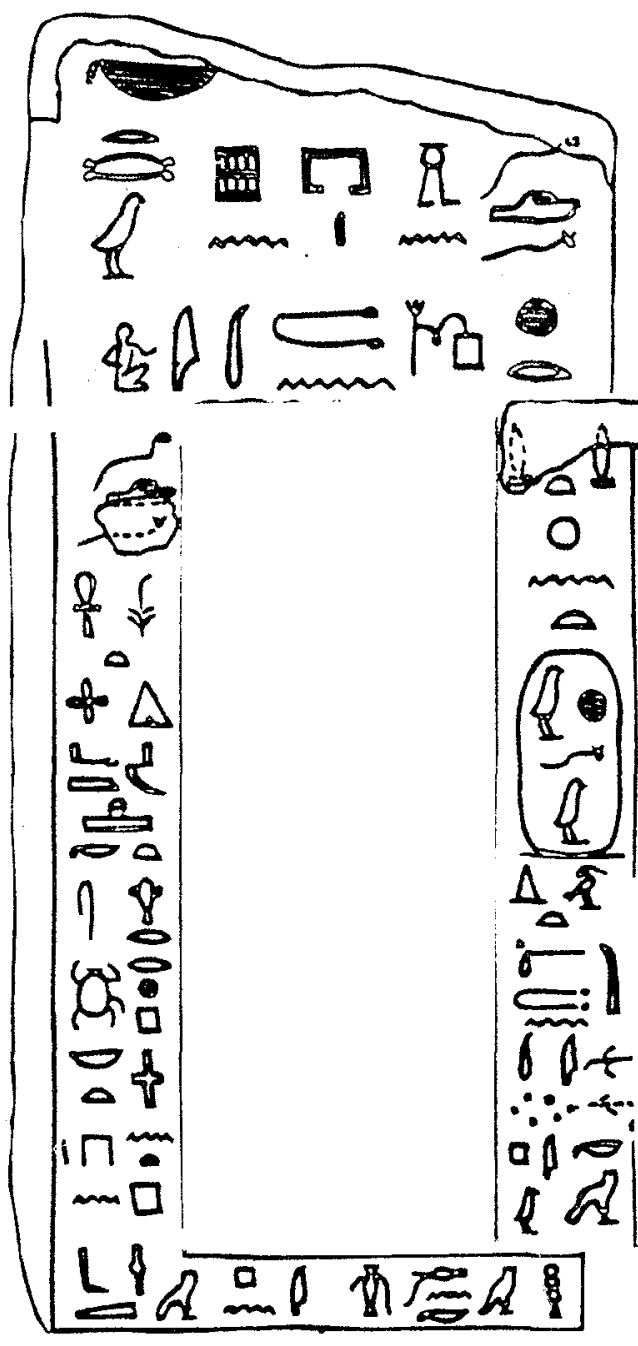

He adquirido esta casa del escriba Tenti $y$ he dado por ella 10 chatis

sellado en la casa del selio, ante el Consejo local de la pirámide de Jeos, y ante varios testigos. (Vienen las firmas de los testigos: obrero mejo y los sacerdotes funerarios Sebni, Ini y Nianjor).

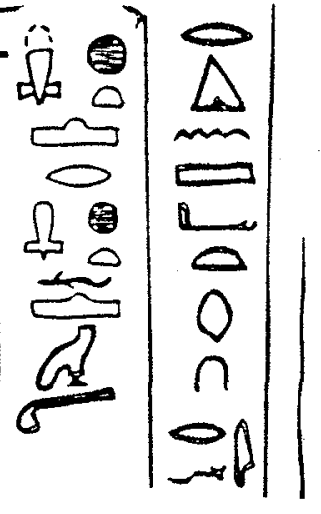

1 mueble de madera de anís, 3 chati; otro de madera de sicomoro, 3 chati; y una cama de madera de cedro, 4 chati.
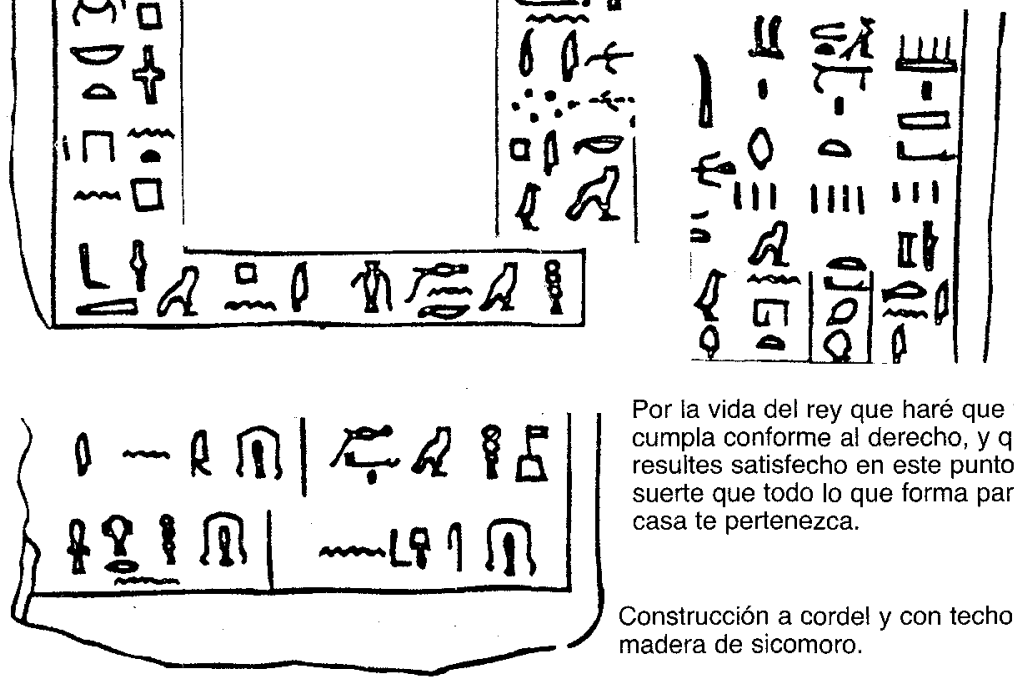

Por la vida del rey que haré que todo se cumpla conforme al derecho, y que resultes satisfecho en este punto de suerte que todo lo que forma parte de la casa te pertenezca.

Construcción a cordel y con techo de madera de sicomoro.

Ilustración 5 bis. Transcripción y lectura de la "estela de Gizeh». 
historia», en su parágrafo 129 dice: «Entre todos los reyes dicen que Micerino fue el que con mayor equidad sentenció las causas de sus vasallos, elogio por el cual es el monarca más celebrado de cuantos vió Egipto. Llevó a tal punto su justicia que, no sólo juzgaba los pleitos todos, con entereza, sino que era cumplido que, a la parte que no se diera por satisfecha en su sentencia, solía contentarla con algo de su propia casa y hacienda».

Pienso pues que, existiendo juicios con sentencias consecuentes a causas planteadas por los administrados, forzoso es admitir idéntica existencia de leyes, ya no desde Menes, sino cuando menos desde el Horus Menkauré de la IV dinastía, o Micerino, que es como lo nombra el historiador griego Herodoto.

Aquí podemos verle, (llustración no 6) en esta escultura de esquisto de 1,5 metro aprox., que se encuentra en el Museo de Boston (EE.UU.), junto a su esposa que lo abraza tiernamente por el talle. La sencillez del grupo escultórico es, simplemente, llamativa.

También es dable pensar que, existiendo contratos de compraventa, como el que acabamos de citar sobre la estela de Gizeh, catalogada como «IE 42.787», tendrían que darse incumplimientos a los mismos, de tal suerte que la reparación a tal responsabilidad, se efectuaría sin duda a través de la satisfactoria sentencia al «petitum» del demandante, bien a través de la aplicación de una justicia real primero y administrativa después, o como fue muy frecuente, de una justicia arbitral.

Y que ésto es así lo comprobamos, entre otras pruebas documentales, a través de las actas de fundaciones funerarias de Khefra o Jefrén, de la IV dinastía, y de las de Senuankh a comienzos de la $V$, que fueron traducidas por Moret en 1907, y comentadas por Pirenne en 1934.

En la primera Acta, de la que hace algún tiempo hice un estudio arbitral que fue acogido en el III congreso Peninsular de Historia Antigua, celebrado en Vitoria (España) en 1994, se comprueba la existencia de, junto a la justicia ordinaria, la justicia arbitral para aquellos conflictos que pudieran surgir entre los cofrades de la fundación funeraria, a través de la inserción voluntaria de una cláusula compromisoria que establecía el procedimiento arbitral - como de idéntica manera sucede hoy en las leyes de arbitrajeapartando a la justicia ordinaria de su conocimiento y, por tanto, de su ejecución.

Promovido el litigio, el procedimiento comenzaba por una demanda escrita sobre los derechos que pretendidamente habian sido conculcados al demandante, por la fundación. Recibida la demanda se nombraba o bien 


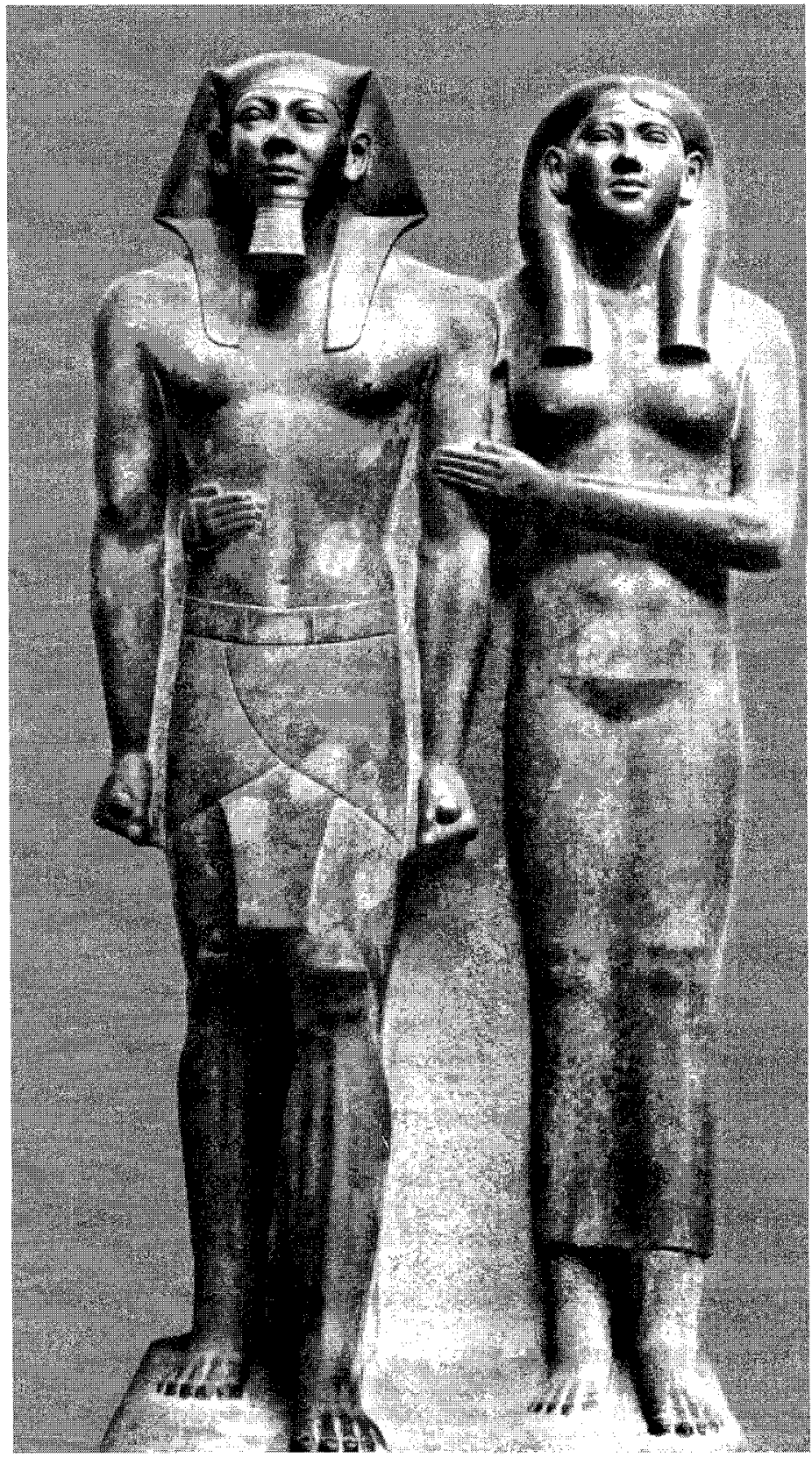

llustración 6. Micerino y su esposa. Museo de Boston. 
un árbitro único o un tribunal colegiado. Se abría un período probatorio en el que el demandante aportaba cuantas pruebas y alegaciones considerara necesarias y a las que hubiese lugar. Una vez aportadas dichas pruebas, tanto las del demandante, como las de la demandada institución funeraria, era pronunciado por los árbitros un laudo arbitral de obligado cumplimiento y absolutamente ejecutorio, pasando a ser a partir de ese momento cosa juzgada e impidiendo ningún tipo de recurso ante la justicia ordinaria. Una vez firme el laudo o sentencia se registraba en papiro en la "Çy n wpiw» (aien upiu), o Casa del Juicio del «T.3ty» (Jati), siendo el registro de la sentencia y la certeza de la misma, una garantía administrativa y una seguridad jurídica absoluta.

De modo que ya, en el Antiguo Imperio, está acreditada la aplicación de la ley y la norma jurídica, tanto por el uso del derecho, a través de los «ïn n.ï $r$ issw» (in nei reisu), o contratos de compraventa; de los «imy pr» (imiper), o transferencia de la propiedad; como también por la petición de justicia y su consecuente administración, alguno de cuyos procesos vamos a comentar más adelante.

Sabemos que los egipcios eran sumamente formalistas y, en materia religiosa, mágicos y ritualistas. ¿Lo eran también en materia jurídica? Sin duda la forma, y por tanto el principio de escritura en los contratos, facilitaba la prueba. El principio espiritualista que, en materia de contratos, rige nuestros Códigos civiles, no cabe duda que hubo de regir en el nacimiento de muchos de los contratos egipcios. La consensualidad de las partes en su celebración, y no la forma, tuvo que dar virtualidad a muchos, haciendo realidad el brocardo «Pacta sunt servanda», por el que los contratos nacen para ser cumplidos, seguramente tuvo que ser la generalidad. En tal sentido el principio espiritualista rigió gran parte del derecho contractual egipcio. Pero no es menos cierto que al objeto de garantizar «erga omnes» los derechos adquiridos por el comprador de bienes inmuebles, el principio formalista regía su vida jurídica. Tal es así que estelas como la de Gizeh no eran otra cosa que el anuncio permanente, o cuasiperpetuo, de que la casa, el fondo o el derecho en la fundación funeraria, pertenecían a aquella persona determinada en el pétreo documento.

Nos damos cuenta así de que figuras jurídicas que consideramos modernas o relativamente cercanas en el tiempo, tienen una venerable antigüedad.

El profesor Kruchten, ha sido hasta la fecha el último que ha estudiado el llamado «Decreto de Horemheb», es decir el Horus Djeserkheperuré, último faraón de la XVIII dinastía. 
Vamos a ver este documento jurídico, tal y como lo fotografíe en 1987 , (ilustración $n^{\circ}$ 7) que se encuentra frente al décimo pilono del ternplo de Karnak y en la actualidad, por la incuria de las propias instituciones administrativas y culturales del país, se encuentra en un grado de deterioro avanzado, como pueden comprobar. Dice Kruchten que las disposiciones que dicta el Horus, con carácter general, se corresponden con la idea concreta que tenemos hoy de ley. En efecto, en este decreto, que trataba de poner orden en el caótico abuso administrativo a que se había llegado desde tiempos del Horus Neferkheperuré Akhenatón más conocido con el nombre griego de Amenofis IV, se pueden apreciar los requisitos que la teoría jurídica moderna contempla como necesarios para expresar el concepto de ley:

1..$^{\circ}$ La existencia de un Estado con una administración pública y un funcionariado jurídico.

2. ${ }^{\circ}$ La existencia de leyes generales, como este decreto que comentamos, con carácter de generalidad, formal y material.

3. Además de lo anterior, la promulgación de la norma por el Horus con toda la solemnidad.

De modo que los egipcios, según la filología, daban a la ley el vocablo "hp" (guep) y a la norma el vocablo "wd" (ud). Así que podemos deducir que desde nuestro actual punto de vista técnico-jurídico, está claro que la expresión guep tiene que ser tomado como «ley», en el sentido estricto que actualmente damos a esa expresión.

Pero fijense Vds. en que también en el Egipto faraónico existía el principio jerárquico de la norma, según hemos constatado los investigadores del derecho egipcio. Había normas que emanaban directamente del Horus a través de su prolación imperativa «hw» (gü), y que para Frankfort, es la orden que encierra un poder intrínseco que impone obediencia. Solamente así se mantiene el orden de la creación o ciclo cósmico eliminador del caos. El Horus, como hijo de dioses y dios viviente él mismo, tiene como fundamental obligación mantener ese orden y ser pastor de sus administrados.

El decreto de Horemheb es un ejemplo de la existencia de normas de «ius cogens" o derecho imperativo como principio regidor del derecho administrativo egipcio.

De ahí que la protección jurídica en la monarquía egipcia empieza en el mismo Horus, dada su función divina. Muchos de los faraones cuando comienzan su reinado establecen en sus títulos reales un verdadero 


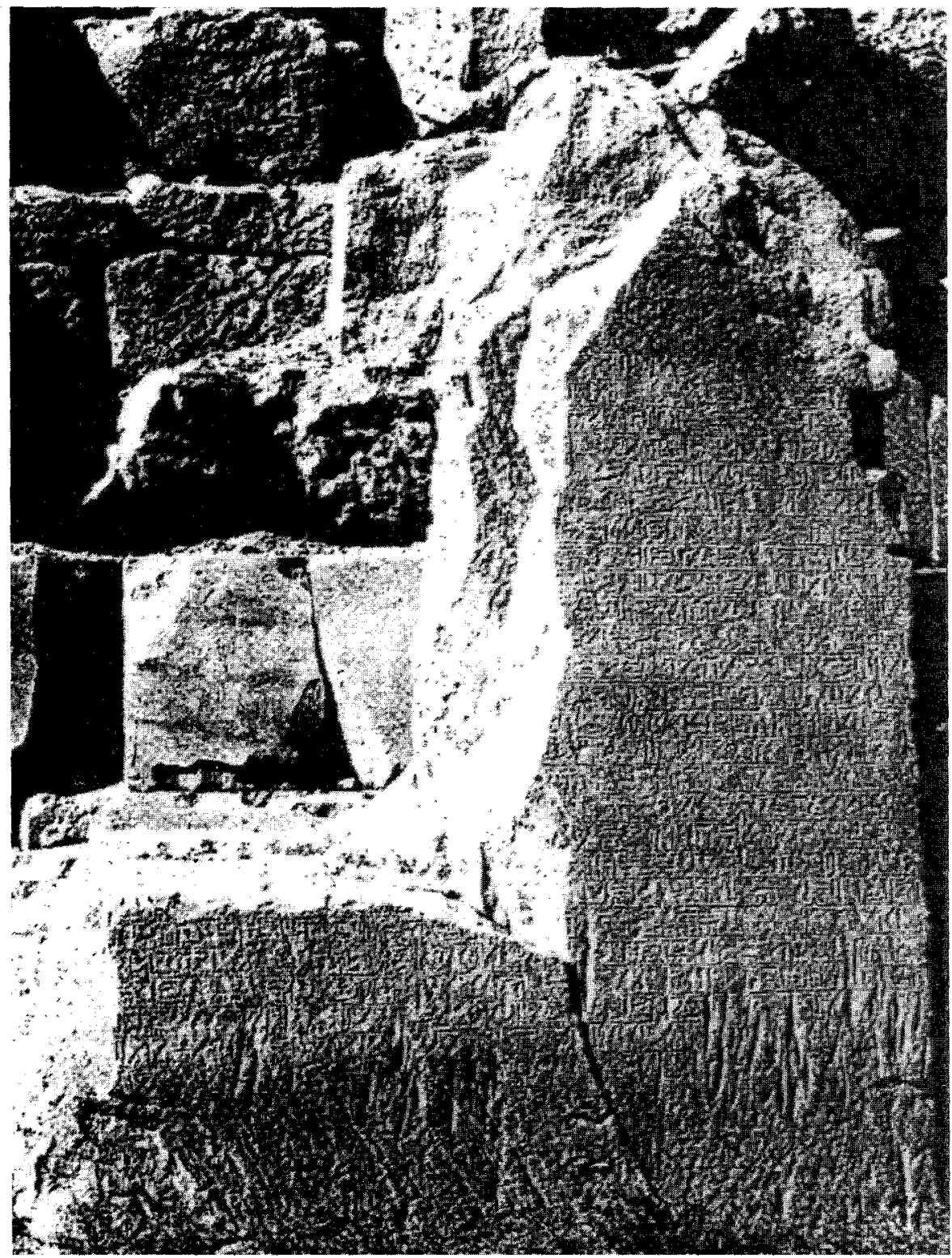

Mustración 7. "Decreto de Horemheb" en Kamak. 
programa de gobierno, preponderando los principios de orden, armonía y justicia. Así entre sus títulos se ve frecuentemente: «El que hace surgir la verdad y destruye la mentira»; "El buen dios»; o como se puede leer entre las líneas 22 y 26 de la "Estela del Louvre, C 286»: "La fuerza es poseída a su gusto, la abundancia se establece gracias a sus leyes. Los caminos están abiertos y libres. $Y$ las dos regiones guiadas con felicidad. El mal se fue, Seth el acusador, se alejó. La tierra está en paz bajo su señor. La justicia está bien establecida. Se vuelve la espalda a la injusticia».

Además de la existencia de la ley en sí, estaba la jurisprudencia creadora del "T.3ty» (jati), es decir el cargo más importante en Egipto después del Horus, y entre cuyos diversos títulos y actividades habría que destacar la de primer ministro y presidente de la corte suprema de justicia.

De modo que el «T.3ty» (jati) es la materialización del derecho por delegación del Horus, por lo menos desde la VI dinastía, allá por el año 2450 a.C.

Dice el insigne historiador belga Pirenne, que contra las decisiones judiciales dadas en cualquier «Sepat», o provincia, podía apelarse ante el tribunal supremo de «Las seis cámaras de Menfis», presidido por el "T.3ty». Esto pasa en el Antiguo Imperio, porque ya desde Nebhepetré, esto es Mentuhotep III en la XI dinastía, allá por el 2060 a.C. es decir en el Imperio Medio, está ya acreditada la existencia de dos «T.3tys», uno para el Bajo Egipto y otro para el Alto Egipto.

El primer «T.3ty» del que tenemos constancia histórica es Nefermaât, hijo de Uni, último faraón de la III Dinastía y muy probablemente hermano de Snefru, primer faraón de la IV.

Reparen en el nombre: «Nefermaât», es decir que traducido significa «hermosa es la verdad», o también «Es bella la justicia». Puesto que el vocablo "Nefer" tiene el significado de "bella", "hermosa" y el vocablo «maat», se traduce como «verdad», «justicia», «orden», como ya hemos dicho anteriormente. Recuerden el nombre tan conocido por todos de "Nefertiti», esposa del llamado faraón hereje "Akhenatón», y cuya traducción es «La bella Titi». O el nombre de otra reina «Nefertari», esposa de Ahmosis, fundador de la XVIII dinastía, y cuya traducción es «la bella Tari».

De modo que desde esa lejana época del «T.3ty» "Nefermaat», hasta la XVIII dinastía, en que vive el "T.3ty» Rekhmiré, que ha pasado a la historia por haber dejado en su tumba una inscripción funeraria que nos sirve 
de mucho a los historiadores del derecho antiguo, el cargo jurisdiccional del «T.3ty» entrañaba una gran responsabilidad.

Al instalarle en su cargo de juez supremo, el Horus indefectiblemente decía: «Mira que tu cago es de gran responsabilidad, porque es estar vigilante, ya que cualquier cosa va a ser hecha en tu nombre. Tienes el apoyo de toda la tierra, pero en verdad que el ejercicio de tu cargo no es un duice camino. En verdad que es amargo como la hiel».

«No hagas un juicio injusto - le diche el Horus Menkheperé (es decir, Thutmosis III, de la XVIII dinastía) - porque el dios detesta tal conducta. Actúa de acuerdo a lo que te digo. Si lo haces así tendrás éxito como Magistrado, porque su mérito es actuar justamente. El dios quiere que la justicia se haga a través del «T.3ty», porque éste es el protector de la justicia. Tu Sala de juicios contiene todos los litigios registrados por lo que actuarás conforme al conocimiento de la ley y los decretos reales».

En general el cargo no era hereditario pero en el caso que estamos comentando Rekhmiré, sucedió a su padre Neferuben, éste a su hermano Useramón, y éste a su padre Aametkhu.

En su tumba Rekhmiré cara a cara con la muerte y el juicio de Osiris, inscribió para la posteridad: «Yo he juzgado por igual a pobres que a ricos. He protegido al débil del fuerte. He sido opositor de la violencia que emanaba del violento. He reprimido al avaro cuando procedía. He neutralizado al colérico con perseverancia. He convertido la tristeza en consuelo. $\mathrm{He}$ defendido a las viudas por su viudez y desamparo. He restablecido en la herencia al hijo y su participación en el haber de su padre. He dado de comer al hambriento, de beber al sediento y todo al que nada tenía. He socorrido con el apoyo de mi bastón al anciano, y la anciana ha dicho: ¡Qué buena obra! He odiado la iniquidad y jamás he caído en ella. He castigado cabeza abajo al mentiroso. He sido el vehículo de la palabra justa de «Maât» ante los dioses. Nadie, ningún otro juez ha dicho de mí ¿Qué ha hecho? Cuando he juzgado causas graves, los contendientes han salido en paz del tribunal. Jamás he pervertido por dádivas a la justicia, ni he sido sordo a las pretensiones del que nada podía ofrecerme. Muy al contrario, jamás he aceptado regalos ni presentes. En mí no se hallará corrupción".

Pero el «T.3ty» no podía extenderse físicamente por todo el territorio de las dos tierras, por lo que pronto se vió la necesidad de una jurisdicción delegada. Así aparecieron los funcionarios conocidos con los nombres de "sb» (sab) y "wp.w» (upiu) que administraban una justicia basada en la equidad, la costumbre, los decretos reales y la jurisprudencia. 
A lo largo del tiempo, el jeroglífico del chacal impreso en sellos, junto al del escriba, se ha venido encontrando en diversas excavaciones como representativo de juez. Así lo estimó Revillout, cuando sostenía hablando del chacal, como dios cinocéfalo, citado también por Harapolón, en período de influencia griega, que el "arké» o magistrado y el "dikastés» o juez, están escritos junto a la representación del perro.

Esto se viene confirmando desde la época ramésida. Es decir, el «ç. $n$ wp.w» (ai en upiu), se traduce como tribunal o "Casa del juicio", algunas de cuyas sentencias transcritas en ostracos, se han encontrado en la villa de los obreros, de la necrópolis de Tebas, en Deir El Medina. Y así hasta la Baja Época, llegando a la época ptolemaica en que la influencia griega se dejaba sentir.

Ostracos, es decir bloques de piedra caliza, sobre los que se escribían generalmente copias o documentos de menor importancia, ya que el papiro siempre fue un material costoso, como el que pueden observar aquí (ilustración $n^{\circ} 8$ ) procedente de la villa de los obreros de Deir elMedina.

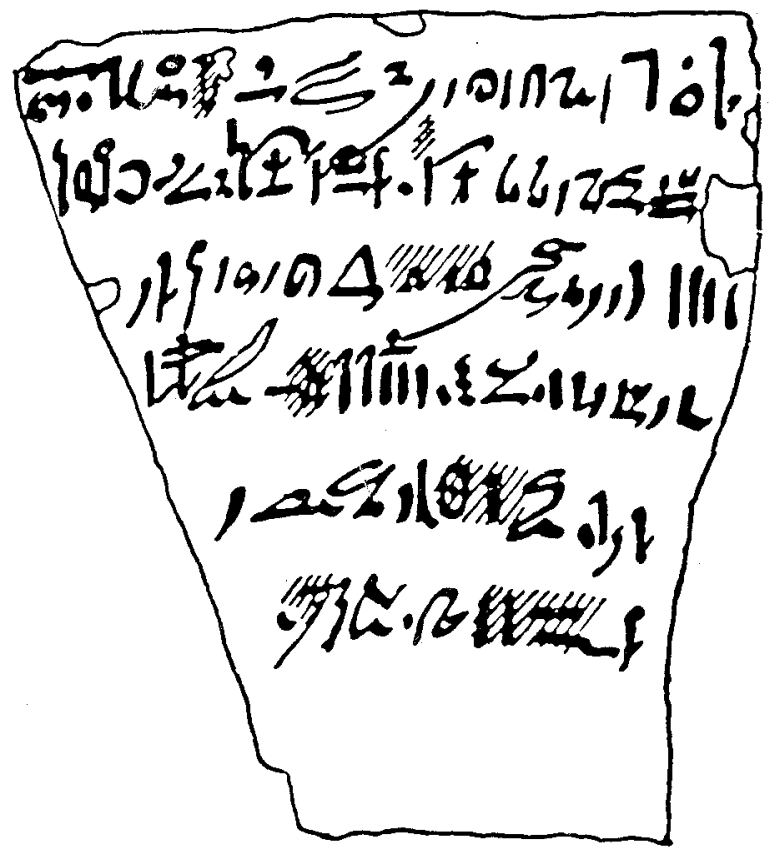

Ilustración 8. "Ostracon» procedente de la villa de los obreros de Deir el-Medina. 
Se trata de una garantía de deuda, escrita por un escriba para un analfabeto, que conservó sin duda, al acreedor hasta el cumplimiento del contrato. Puede fecharse en la época ramésida, entre Ramsés III y IX, es decir entre los años 1166 y 1085 a.C., y que se encuentra en la Petrie Collection, del University College de Londres, y se puede traducir así:

«Año V, mes III de Peret, es decir el invierno, día 22. Lo que el guardián de la hacienda, Penrenenuet dijo: Por Amón y el soberano: Si pasa una semana de lo establecido sin haber entregado esta túnica a Harmin, la deuda se doblará contra mí. Acuerdo escrito por el capataz de la cuadrilla. Nekhemmut».

Los procedimientos judiciales se regulaban con el mayor detalle, concluyendo con una sentencia que era registrada en la oficina administrativa del "T.3ty». La estructura del procedimiento contemplaba un peticionario de justicia a su caso concreto, es decir el demandante. El juez o árbitro a quien se dirigía la petición, y el demandado o deudor en el asunto litigioso.

Aún no sabemos con certeza si la demanda era oral o escrita, pero suponemos que en los primeros tiempos sería oral, sobre todo cuando era el Horus el que impartía directamente la justicia, para evolucionar al registro escrito a lo largo del Imperio Antiguo, cuando menos los Decretos reales que nos han llegado, sin duda como consecuencia de sentencias «in voce» que necesitaban quedar registradas para casos semejantes, ya que probablemente hasta el Imperio Medio, en los casos comunes preponderó la justicia arbitral.

A finales del Antiguo Imperio ha quedado registrado en una cámara funeraria el proceso penal de Uni que, sin duda fue oral. Pasada esa fase, se transformó en un procedimiento mixto, y concluyó en otro estrictamente escrito y documental, del que dejaban nota fehaciente los escribas judiciales, en los archivos para su posterior consulta y emisión de copias a petición de los interesados, o de los jueces.

En la tumba del escriba del dios Ptah, Khayri (Jairi), en Saqqara, necrópolis de Menfis de la época del Horus Usimaré (Ramsés II, 13011234 a.C.) se encuentra documentado un pleito sobre la herencia de Neshi (Nesgui) de enorme duración y que merece la pena describir por el conocimiento que nos aporta sobre el desarrollo de los procedimientos judiciales.

El Horus Nehpehtiré, esto es, Ahmosis que reinó de 1580 a 1558 a.C.), fundador de la XVIII dinastía, regaló al patrón de barcos Neshi (Nesgui), 
13 arure de tierra cultivable, equivalente a 3 hectáreas, al sur de Menfis en la orilla izquierda del Nilo. Este fundo pasó, en calidad de herencia, a través de diversas generaciones, hasta el protagonista. Reinando alguno de los reyes del período amarnense, probablemente Kheperkheperuré, llamado $\mathrm{Ai}$, de 1344 a 1340 a.C., la herencia pertenecía a 12 hermanos, 6 varones y 6 hembras, y administraba la tierra Urnero, una de las hermanas que estaba casada con Prehotep (Pregotep), de cuyo matrimonio tuvo un hijo llamado Hwy (Güi), que era el que por cesión, cultivaba la parte correspondiente a su madre. Por esas fechas una hermana de Urnero, llamada Takharu (Tajaru), reclamó la administración de la tierra, promoviendo un pleito contra su hermana, que se resolvió por el magistrado presidente del tribunal, el sacerdote-funcionario Aniy que falló el reparto equitativo de la tierra entre todos los herederos.

Por otro lado, el esposo de Urnero, contrajo un nuevo matrimonio, fruto del cual resultó su hijo Tjawi (Jaui). Con ese motivo Prehotep (Pregotep), no se sabe cómo, registró la tierra que pertenecía a Urnero, a nombre de su hijo Tjawi (Jaui). Los hechos precedentes parece ser que ocurrieron reinando el Horus Djeserkheperuré, conocido como Horemheb, de 1344 a 1314 a.C.

Más tarde, reinando ya Usimaré, es decir Ramsés II, desde 1301 a 1234 a.C. el registro ilegal de propiedad de la tierra efectuado por Prehotep (Pregotep) en su dia, y con motivo de la muerte de su hijo Hwy (Güi), se promovió un nuevo litigio, al intentar Khayri (Jairi), el hijo del difunto Hwy (Güi), cultivar la tierra de su abuela Urnero, e impedirselo Khay (Jai) el nieto de Tjawi (Jaui), que se consideraba el propietario por título de herencia de su abuelo Prehotep (Pregotep).

El pleito lo inició la esposa del difunto Hwy (Güi) en el año 14 del Horus Usimaré. En el año 18, Khay (Jai) presentó al tribunal, en defensa de sus derechos, los documentos que acreditaban el registro de la tierra a nombre de su abuelo Tjawi (Jaui), declarando en su contestación a la demanda, que realmente Hwy (Güi), el padre del demandante, había sido un simple bracero. Con esas falsas pruebas, y con la aparente legitimación del registro, el tribunal, cuyo magistrado presidente era el sacerdote funcionario Amenemope, falló el pleito a favor del demandado Khay (Jai).

Ante tan injusta sentencia que desposeía a los verdaderos propietarios de su bien inmueble, Khayri (Jairi) y su madre que aún vivía, promovieron un recurso de apelación ante el tribunal supremo de Heliópolis, ante el mismo «T.3ty», quien ordenó que se trajese la escritura del Registro de la residencia real, que en esos momentos estaba en el Delta, en la ciudad de $\mathrm{Pi}$-Ramsés, y con la que pudo comprobarse que, en efecto, el nombre de 
Khayri (Jairi) no aparecia por ningún lado. Ante las protestas de veracidad de éste en su contestación al Recurso, el "T.3ty" decidió que el tribunal de Menfis instruyese una nueva fase testifical, todo lo amplia que fuese necesario. $Y$ en ella testificó el cabrero Mesman, quien bajo juramento dijo: "Como es cierto que el dios Amón es eterno, y también el Horus, Vida, Salud y Fuerza, lo es, diré la verdad. No mentiré, y si miento que me corten la nariz y las orejas y que me destierren al País de Kush. Se cuenta que Hwy (Güi) el escriba, hijo de la ciudadana Urnero, es el «ms» (mes) de Neshi (Nesgui)». (Hay que aclarar que «mes» significaba en egipcio hijo y heredero.)

Al fin el tribunal debió llegar al convencimiento necesario para revocar la anterior sentencia y fallar a favor de Khayri (Jairi), expresando en el Fallo que, en efecto era descendiente de Huy (Gui), su padre, y de su abuela Urnero, y así hasta remontarse al patrón de barcos Neshi (Nesgui) y por tanto su «mes» o heredero.

Y la inscripción funeraria concluye expresando: «Me dieron la tierra. Trece arure me dieron como heredero, ante los notables de la ciudad. $Y$ en la sala del juicio se puso una copia del Fallo del tribunal junto con el nombre de los jueces sentenciadores».

Como hemos podido comprobar por esta descripción, los egipcios disponían de un derecho procesal que, a grandes rasgos, nada se diferencia dẹ nuestro: Demandas, contestaciones, réplicas, dúplicas, fases probatorias con confesión, documental y testifical, conclusiones y sentencia emitiendo un fallo, a veces no ajustado a derecho, pero exactamente igual a como ocurre en la actualidad. Recursos a tribunales superiores, revisiones de las sentencias, casaciones, en fin, igual que ahora.

La diferencia es que hace 4.500 años ya lo hacían los egipcios, y ellos enseñaron a los griegos, estos a los romanos y éstos a su vez, a la cuenca mediterránea occidental, que fue el crisol donde se fundieron los derechos romano y germánico, a los que se unió más tarde el canónico. Pero los conceptos, figuras e instituciones de esos derechos estaban subsistentes en aquello que los romanos creyeron haber creado: El Derecho.

No fue así, y aunque se pretenda acallar a la historia, la historia nos demuestra que fueron los egipcios quienes influyeron en las civilizaciones griega y romana.

No es Grecia, con su filosofía o su geometría, la cuna de la civilización, porque esos conocimientos los aprendieron Tales, Anaximandro, Pitágoras y Solón, de los templos egipcios. 
No hay más que leer la epístola de Tales a Ferécides, cuando le dice: «...habiendo navegando a Creta a fin de hacer nuestras observaciones y a Egipto, para comunicarnos con los sacerdotes y astrónomos, lo dejamos de hacer ahora para ir a verte...".

Y aún hay más: La propia Atenas fue fundada por una colonia egipcia al frente de Kekrops, en el siglo xvIII a.C. y su primer rey, Erecteo el hijo de Paudián, era egipcio.

No es Roma, con su llamada creación del Derecho y de las instituciones, ni con sus Doce Tablas del año 451 a.C., que no era otra cosa que un derecho de labradores, que habían copiado los «decenviri legibus scribundis» de los derechos municipales griegos, llevándolos a aquella Roma incipiente, la cuna de la civilización. Porque esos conocimientos los adquirieron por préstamo, primero de los griegos, y después de la Escuela jurídica de Berito, cuyos jurisconsultos fenicios habian bebido de las fuentes orientales, influenciadas fundamentalmente por Egipto. Es por tanto Egipto, la cuna auténtica de nuestra civilización.

Lo que ocurre es que a los juristas se nos enseña una historia del derecho que comienza por Roma, diciéndonos que Roma es la «mater et magistra" del derecho. De tal suerte que el derecho parece nacer, como por generación espontánea, a partir del nacimiento de Roma, y no antes. Esto ocurre porque nuestras Universidades son de corte romanista, petrificado e incapaz de profundizar en las raíces más hondas del derecho, que llegan, como no podía ser menos, a los comienzos históricos del hombre, por un lado en "el cuerno fértil» mesopotámico de Sumer, con sus «códigos» de Shulgi en el 2100 a.C., o de Lipit-Ishtar, de 1934 a.C., por no citar al conocidísimo «Código de Hamurabi», de 1700 a.C. Y por el otro, en Egipto donde vamos comprobando un derecho técnico, a la vez que práctico, y que lejos de haber muerto se encuentra redivivo en multitud de instituciones de nuestro derecho actual, sin apenas cambios dignos de mención.

Vean si no el derecho del arbitraje egipcio, el de Roma y el nuestro. Verán que son iguales.

\section{Segunda Parte:}

a) El Derecho de Familia:

Tiene razón Kinsey cuando dice que «mientras las instituciones económicas, políticas y educativas son estudiadas intensamente, se dedica muy 
poco lugar al estudio de la familia. No existe nombre alguno para la ciencia de las relaciones de familia como institución social».

En la antigüedad más remota se tenía conciencia de la institución como un grupo de personas que basan su relación en la consanguinidad y afinidad que se establece a través del vínculo biológico de las relaciones sexuales y reproductivas y creando entre ellos una relación tendencialmente duradera. Estamos hablando no de la prehistoria ni de la protohistoria, sino de la historia, y exceptuando microculturas, sin evolucionar desde la edad de piedra, que aún podemos encontrar en algunas zonas remotas del globo.

Si bien no puede darse un concepto univoco del matrimonio, si podemos decir que el acto matrimonial es la voluntad recíprocamente formulada entre un hombre y una mujer, pública y solemnemente, de constituirse en cónyuges tendencialmente permanentes. La unión carnal constituye y perfecciona el estado matrimonial con los derechos y deberes que tal sociedad comporta. De este acto surge de inmediato la familia, como célula independiente y socialmente reconocida, y también regulada por el Estado que fiscaliza la institución matrimonial, solemnizándola, procurando su estabilidad y aplicando remedios jurídicos a sus crisis.

En la actualidad uno de los indicadores de la degeneración de los Estados en los finales del siglo $\mathrm{xx}$, es precisamente el matrimonio y su célula familiar. Hoy comprobamos como los llamados países del «Estado del Bienestar», avanzados y europeos, en fin, aquellos que podemos incluir en la órbita occidental, promueven e incluso instigan las uniones libres, los matrimonios homosexuales y las familias monoparenterales, las adopciones de menores por matrimonios de lesbianas, etc., al amparo de una pretendida libertad inherente al hombre (ser humano).

Semejantes aberraciones de un extendido criterio social han erosionado el concepto clásico del matrimonio hasta límites insospechados, debido a una carencia ética, una crisis de valores y aún de conceptos que, con un afán excesivamente iconoclasta, han sido derrumbados sin ser, hasta la fecha, sustituidos por otros, aceptados como valiosos.

Respecto a la nupcialidad, ha quedado en el más bajo nivel en lo que va de siglo, según un informe reciente del Instituto de Estudios Sociales francés, que indica las 254.000 bodas celebradas en 1995, contra las 417.000 celebradas en 1972 .

Francia tiene la tasa matrimonial, junto a Suecia, más baja de Europa occidental, con un $0,44 \%$ de matrimonios por año y el número de parejas 
no casadas ronda los 2.200.000. En España la tasa de matrimonios celebrado por año está en el $5 \%$.

La anarquía es total. Esta «libertad para todo, incluído el matrimonio» origina, traducido a datos estadísticos, que en Estados Unidos el $50 \%$ de los matrimonios acaba en divorcio. En Suecia el $43 \%$. En Francia el $38 \%$. En Italia el $29 \%$ y en España estamos ya muy cerca del $24 \%$. Si nos percatamos de que estamos hablando de cifras de divorcios, y no de separaciones, ni de rupturas de uniones libres, matrimonios de hecho, etc., llegaremos a la conclusión con estas escalofriantes cifras, de que la institución matrimonial está sumida en una auténtica crisis de muy difícil solución.

En Egipto, la protección jurídica a la familia presentaba los siguientes principios básicos:

Era un modelo patriarcal y nuclear, estando formado por los cónyuges, ocasionalmente sus padres, los hijos, sus esposas, y, quien económicamente pudiese permitírselo, concubinas.

Era patrilineal y patrilocal. La mujer se trasladaba a casa del marido y la filiación de los hijos era, comunmente paterno-materna.

El principio de solidaridad familiar era una de las características más llamativas, como unidad social y económica, con una auténtica reciprocidad asistencial. Esto lo podemos contemplar en el caso de la fianza familiar como garantía de pago por una deuda, que describe el papiro Brooklyn, para el supuesto de incumplimiento por el obligado, donde será la familia quien le supla en la prestación forzosa de trabajo; o la condena a prisión de la familia de un soldado desertor, que describe el papiro Lansing; o la condición servil a que se lleva a la familia por un impago fiscal, según el papiro Anastasi V. (versus).

Importante principio era la propiedad indivisa de bienes y su libre disposición, con lo que se daba el disfrute de un derecho comunitario sobre los mismos que estaban bajo la "potestas", primero del padre, y luego del primogénito, generalmente a través de la institución del mayorazgo, administrándolos en calidad de «rwd» (rud) o mero administrador, o bien repartiéndolos entre los demás miembros de la familia, que eran depositarios de un derecho expectante a la herencia.

Otro principio, no menos importante, fue el de primogenitura que sufre algunas oscilaciones a través de los tiempos, pero en términos relativos puede decirse que fue general, de tal suerte que lo vemos establecido desde el Antiguo Imperior hasta el llamado «Código de Hermópolis», que 
ha sido atribuido al desgraciado faraón Bokhoris, único de la XXIV dinastía, en el 720 a.C. y al que Diodoro, precisamente, cita como uno de los 6 grandes legisladores de Egipto.

$Y$ en cuanto al derecho a la herencia del patrimonio familiar, se contemplaba la cuota obligatoria o «legítima» y el orden de sucesión por la línea descendente, a través del primogénito varón sobre la colateral. Careciendo de líneas, la herencia se transmitía a extraños.

En el llamado «Papiro de las Adopciones», estudiado por Théodoridés, y que data de Ramsés XI, en 1.113 a.C. "Nbnfr» (Nebnefer) que fallece sin hijos, deja como "ïwçwt» (iaut) heredera de su patrimonio a su esposa "stkh nnfr» (Sutej Nenefer), a través de un «ss n.çi» (sesen ai), es decir, un escrito a su favor, o como diríamos hoy, un acto de disposición patrimonial, en calidad de legataria universal. Esta mujer tenía una sierva que era madre de 3 hijos, los cuales podrían haber sido del causante, si nos fundamos en el reparto que hace Sutej: A una de las hijas de la sierva, la casa con su hermano «Pdw» (Padeu), adopta a los 3 hijos de la esclava, y a su hermano Padeu e instituye a todos ellos como herederos por iguales partes.

El Papiro Boulag $X$, en sus líneas 10 y 11, expresa: “Dice el Horus, Vida, Salud y Fuerza: A quien entierra a sus padres se debe entregar la propiedad». Podemos apreciar que el bondadoso principio moral de enterrar a los muertos, que muchos siglos más tarde quedará reflejado en las obras de misericordia de la religión católica, era un mandato jurídico en el Egipto faraónico desde tiempos inmemoriales. No otro fundamento tienen las fundaciones funerarias desde el Antiguo Imperio.

También cabía el testamento bajo condición, según consta en el papiro «Louvre 2439», donde observamos que Peteharpes entrega todo su patrimonio a su esposa a condición de que lo cuide en vida y a su fallecimiento disponga del embalsamiento y entierro.

La constancia jurídica del matrimonio quedaba reflejada a través de la formalización de un contrato que se efectuaba entre los contrayentes. No tenemos hasta la fecha ningún «imiper», o documento traslaticio anterior a la época ramésida, lo cual no quiere decir que el derecho matrimonial fuese inexistente antes de ese tiempo, como ya he tenido ocasión de expresar en diversos foros. No hay más que ver la existencia de los vocablos "hmt" (guemet) esposa, y "h3y» (gai) esposo. Incluso para Cerny, al que sigue Théodoridés en este aspecto, el vocablo «hb" (gueb) y la expresión «ir hb .f» (ir gueb if), significarían «matrimonio» o «casarse», y «celebrar su matrimonio o boda», respectivamente, según se desprende del estudio 
que hizo el citado Cerny del ostracón datado con el n. ${ }^{\circ} 5634$ en el Museo Británico.

Pero dentro de la vorágine de preguntas que nos asaltan, una es: ¿Cuál era el contenido del contrato matrimonial? Parece acertado pensar, junto con Pirenne, que desde las primeras dinastías el contrato matrimonial contenía un inventario de los bienes que cada contrayente aportaba al haber conyugal. Con el transcurrir del tiempo histórico, ya en la XXII dinastía el iter contractual se había definido más estrictamente, hasta el punto de contener una "cláusula provisora" o de "subsistencia", garantizándola a través de los bienes que el marido tendría que entregar a la mujer ante un eventual repudio. Todo ello independientemente, tanto de los bienes privativos que hubiese aportado la mujer, como de los adquiridos por ésta constante matrimonio.

Vamos a comentar algunos formularios contractuales que nos han llegado de la Baja Época, es decir las dinastías comprendidas entre la XXI y la XXX, entre los años 1085 al 341 a.C.

Un primer modelo, conocido como «sp» (sep) dice asi:

«Yo te tomo por mujer y te doy... (y aquí se describe una nómina de bienes que aporta el marido para la esposa). Si te repudio mientras eres mi mujer, por aborrecerte y querer a otra distinta, en tal caso te daré... (y sigue otra relación de bienes que habría de entregar el marido) y también te daré un tercio de lo que adquiramos juntos a partir de este momento.

Los hijos que me has dado (lo cual nos inclina a pensar que muchos de estos contratos se hacían con posterioridad a la unión conyugal, incluso varios años después. Desroches-Noblecourt así lo cree también, e incluso asegura que existía una forma de matrimonio «a prueba», que al consolidarse daba nacimiento a este tipo de contrato matrimonial que estamos comentando). $Y$ sigue diciendo el contenido de este contrato: "y que aún puedas darme, son los herederos de mis bienes y de lo que pueda adquirir en el futuro. Tu hijo primogénito y mi hijo primogénito... (Aquí termina el documento contractual, al que le falta el resto por encontrarse muy deteriorado).".

Un segundo modelo, descubierto por los arqueólogos, es el que denominamos «hd $\mathrm{n}$ ïr hmt» (guedenir guemet) y que se traduce como «dinero para ser esposa», el cual contempla en este caso una amplia aportación femenina al haber patrimonial del matrimonio. Dice así el marido:

«Tu me has dado... (y se lee una relación de lo aportado por la mujer en cobre y otros objetos) ...como dinero para ser mi mujer. Yo lo he recibido de tu mano, y mi corazón se alegra. Lo he contado y estoy conforme. De ma- 
nera que ni ahora ni nunca haré reclamaciones sobre lo entregado. Y por mi parte entregaré... (aquí se indica una cantidad en grano y plata) para que te mantengas cada año. Si me reclamas el valor de la dote que ahora has aportado y no te la entrego en el plazo de un mes, quedaré obligado a mantenerte como hasta ahora. Tienes derecho por tanto a los pagos a que me obligo para mantenerte".

Un tercer modelo, llamado «çk hbs» (ak guebes) y traducido como "capital de alimentación, contempla fundamentalmente una especial cláusula de pensión alimenticia para la esposa. Dice así:

«Tu me has dado... (y se especifica la dote que aporta la mujer) para sufragar tu pensión alimenticia. Yo la he recibido como precio para tu alimento y vestido. Como contraprestación tienes derecho a un tercio de todos mis bienes presentes y futuros, en representación de los hijos que me has dado y de los que me puedas dar, y además tienes derecho a recibir una pensión a mi cargo. Por mi parte no podré decirte ¡Toma tu dote!, pero si eso es lo deseas (esto significaba la ruptura del contrato matrimonial y por tanto el divorcio y la disolución de la sociedad conyugal) entonces yo me veré obligado a devolvértela. Lo que he dicho lo garantizo con todos mis bienes presentes y futuros".

Todos estos contratos se hacian con el necesario formalismo que requería el derecho. Eran firmados por los contratantes, los testigos, y el escriba que, como fedatario público, garantizaba la inscripción en los registros del T.3ty.

Como podemos ver en estos modelos se contienen los requisitos esenciales de cualquier contrato de obligar en nuestras modernas construcciones jurídicas. Es decir, como primer requisito, el consentimiento de las partes. Segundo, el objeto cierto que sea materia del contrato, $y$, por último, causa de la obligación que se establezca.

Los contratos matrimoniales que estamos comentando, de la época ramésida, sufren una evolución realmente no sustancial, en el período ptolemaico.

De tal suerte que los contratos matrimoniales ptolemaicos que han sido estudiados por mí, y publicados recientemente por la Universidad de Oviedo, y que también trataron Winand y Allam, concluyen con un contrato sobreañadido, conocido como «sygjoresis» o cláusula garante.

Cuando la dinastía lágida, fundada por Ptolomeo Sóter en el 305 a.C., traslada la capital del Egipto faraónico a Alejandría, traslada también costumbres e instituciones griegas, como no podía ser menos, porque griegos macedonios fueron quienes acompañaron a Alejandro en sus conquistas, 
entre las cuales se encuentra el «ierozytai», como un órgano colegiado de «hierothytes» (ierozites) con funciones de carácter religioso.

Sin embargo por un fenómeno osmótico, típicamente egipcio, aquella función garantizadora de los contratos matrimoniales, que hemos visto en los anteriores modelos, y que realizaban los escribas sacerdotes egipcios como notarios a través de su inscripción registral, de los bienes aportados al haber conyugal, ante un eventual divorcio, va a ser absorbida por el derecho ptolemaico con idénticas funciones y con la única diferencia de la sustitución por los nombre griegos de «ierozytai» y «ierothytes» (ierozites).

Y los contratos matrimoniales acabarán denominándose "sygrafé trofitis», cuando contemplan el acuerdo genérico por el que el marido reconocía para la mujer la entrega de bienes inmuebles o muebles, y cuya cláusula en lenguaje demótico, se conocía como «sh n" (chen), o «bienes de alimentación» para la esposa, con un compromiso marital de su mantenimiento constante matrimonio, y añadiendo una cláusula de garantía prendaria a favor de la esposa, con los bienes presentes o futuros del esposo, para el supuesto de un eventual divorcio. Precisamente esa cláusula de garantía prendaria, que se suscribía en el documento, era lo que se denominaba en griego «syggrafé pradeos propasis» y en demótico «sh n db3 hd» (chen deba gued).

Ya ven Vds. como el derecho y las instituciones egipcias, no sólo subsisten en la dominación lágida, sino que se infiltra e impregna, hasta absorverlos totalmente en los contratos matrimoniales alejandrinos que eran, como ven, de factura griega.

Pero surgen más preguntas en sede de matrimonio egipcio: Así, por ejemplo, ¿existía el matrimonio consanguíneo? Y si es así, ¿era la generalidad o la particularidad?

Sobre esto corre, incluso entre científicos, una leyenda, además de equívoca, absurda: La de los frecuentes matrimonios consanguíneos entre la realeza egipcia, y como necesario corolario, la de todos los egipcios.

Nada más incierto. Es verdad que, en las primeras dinastías, se suponen matrimonios consanguíneos entre hermanos, por los datos que nos han Ilegado. Tal es el caso de Snefru, de la IV dinastía (2600-2750 a.C.), casándose con Heteferes, hija del Horus Uni. Ambos eran hijos de este faraón, uno de la esposa principal y otro de una esposa secundaria. Por tanto eran hermanastros. A ello hay que añadir que a Snefru, «se le supone», hijo de Uni, pero nada cierto se sabe.

Lo mismo puede decirse de Micerino, casado con su hermana mayor, y de Shepseskaf, con su hermanastra o el de Sekenenré Taa II, de la di- 
nastía XVII, vasallo del rey hicso Apopis, que casó con su hermana Aahotep, o en la dinastia XIX, el caso de Usimaré (Ramsés II) casado con su hija Binet-Anat, o en la XXI, el caso de Smendes o Pinedjem, que casó con su nieta y su hermana de doble vínculo. Pero además de no ser lo frecuente, sino lo anecdótico, tendríamos que explicar que esos matrimonios eran «deistas y monárquicos», quiero decir que eran la forma de acceder al poder y solían casarse con hijas auténticas del faraón anterior mientras ellos eran simplemente segundones, o advenedizos. La única forma de acceder al trono era casarse con esa hija real, de sangre verdaderamente real por ambas ramas, mientras el pretendiente lo era sólo por una de las ramas, generalmente esposas secundarias. Esa es la explicación a esos no frecuentes matrimonios reales. Por otro lado no podemos dejar de lado la teología osiriaca, donde el fundamento teológico radica precisamente en ese drama osiríaco y la relación del dios Osiris con sus hermanas Neftis e Isis, desde las primeras mitologías, al objeto de conservar "la pureza de la sangre».

Si a todo esto le añadimos la confusión que se ha creado entre los investigadores sobre determinadas expresiones en el lenguaje familiar egipcio, como era el de «snt» (senet) hermana, y «sn» (sen) hermano, es decir que entre marido y mujer se llamaban coloquialmente «hermano" y «hermana", en vez de "hmt" (guemet), mujer, como esposa, y "h3y» (gay), como marido, no debiera extrañarnos el gran confusionismo creado en este campo.

Un ejemplo clarísimo lo tenemos en la carta que dirige la dama Irti a su difunto marido Seankhenptha (seanjenta). Entre otras cosas, para lo que aquí interesa, dice así: «Ved una "hermana" que habla a su "hermano" difunto, y un hijo que habla a su padre difunto".

Respecto a este punto lo único que parece estar acreditado es que, en efecto, en la dinastía ptolemaica, sin duda inspirados en la greco-macedónica, se practicó el matrimonio consanguíneo entre los reyes Ptolomeo Filadelfo, con su hermana Arsinoe; Ptolomeo Filometor con Cleopatra II, y Ptolomeo Filopator con Cleopatra VII, que es la que todo el mundo conoce por sus amores, primero con Julio César y luego con el desgraciado Marco Antonio.

De modo que el matrimonio consanguíneo puro, del que tengamos constancia histórica, no se dió en Egipto, excepto casos muy puntuales y a nivel real.

Otra pregunta que nos surge es: ¿Fué el matrimonio monógamo o polígamo? 
Entre otros muchos autores de renombre, Vercoutter y Théodoridés sostienen que el matrimonio egipcio fué monógamo.

Hemos de decir que, desde el punto de vista jurídico no hay el más mínimo indicio filológico, literario, arqueológico o histórico, no digamos jurídico, donde se acredite que el matrimonio era necesariamente monógamo, sino todo lo contrario.

El matrimonio egipcio era una cuestión privada en cuanto a contrato, por tanto podían contraerse uno o varios matrimonios simultáneos siempre que se garantizase, ante un eventual divorcio, la sobrevivencia alimenticia de la mujer. De ahí los contratos matrimoniales que, en contra de lo que algunos aún puedan creer, no se trataba de un contrato matrimonial "per se", sino de una garantía contractual ante una crisis en ese estado matrimonial, y en el que la administración estatal egipcia no entraba.

No entraba en el matrimonio, entraba en la resolución de sus crisis.

Que el matrimonio era jurídicamente polígamo lo tenemos acreditado a través de varios ejemplos, e independientemente de la institución del concubinato. Autores de la categoría de un Pirenne, Murray, Desroches o Rachewiltz, por no citar a más, coinciden en nuestra teoría del matrimonio polígamo, jurídicamente hablando. Otra cosa muy distinta es que en la realidad cotidiana, la poligamia fuese restringida, debido a la carencia de recursos económicos para el mantenimiento de varias esposas, y sobre todo para el cumplimiento de las cláusulas contractuales a que se obligaban los esposos al instituir su matrimonio.

Por todo ello, como ya lo he dicho en otras ocasiones, el matrimonio polígamo siendo lícito, fue infrecuente por cuestiones económicas simplemente.

Veamos ahora (ilustración n.ํ) algunos ejemplos de poligamia: En el Boston Museum of Fine Arts, se encuentra el grupo escultórico que representa a Wekh-hopte (Uejopte), que vivió en el reinado de Sesostris II o III, es decir en la XII dinastía, entre el 2000 y el 1785 a.C., y que fue el propietario de la tumba catalogada como C.1, en la villa de Meir, al sur de Amarna, con sus dos esposas llamadas Khnemhotep (Jenengotep) y Kebkau, y sosteniendo a una hija pequeña.

En el papiro Mayer, que se encuentra en el Museo Británico, se describe un proceso penal, en cuyo desarrollo aparece un ladrón de tumbas que tuvo 4 mujeres, de las que aún vivían dos, cuando los guardias de la necrópolis le sorprendieron en pleno saqueo. 


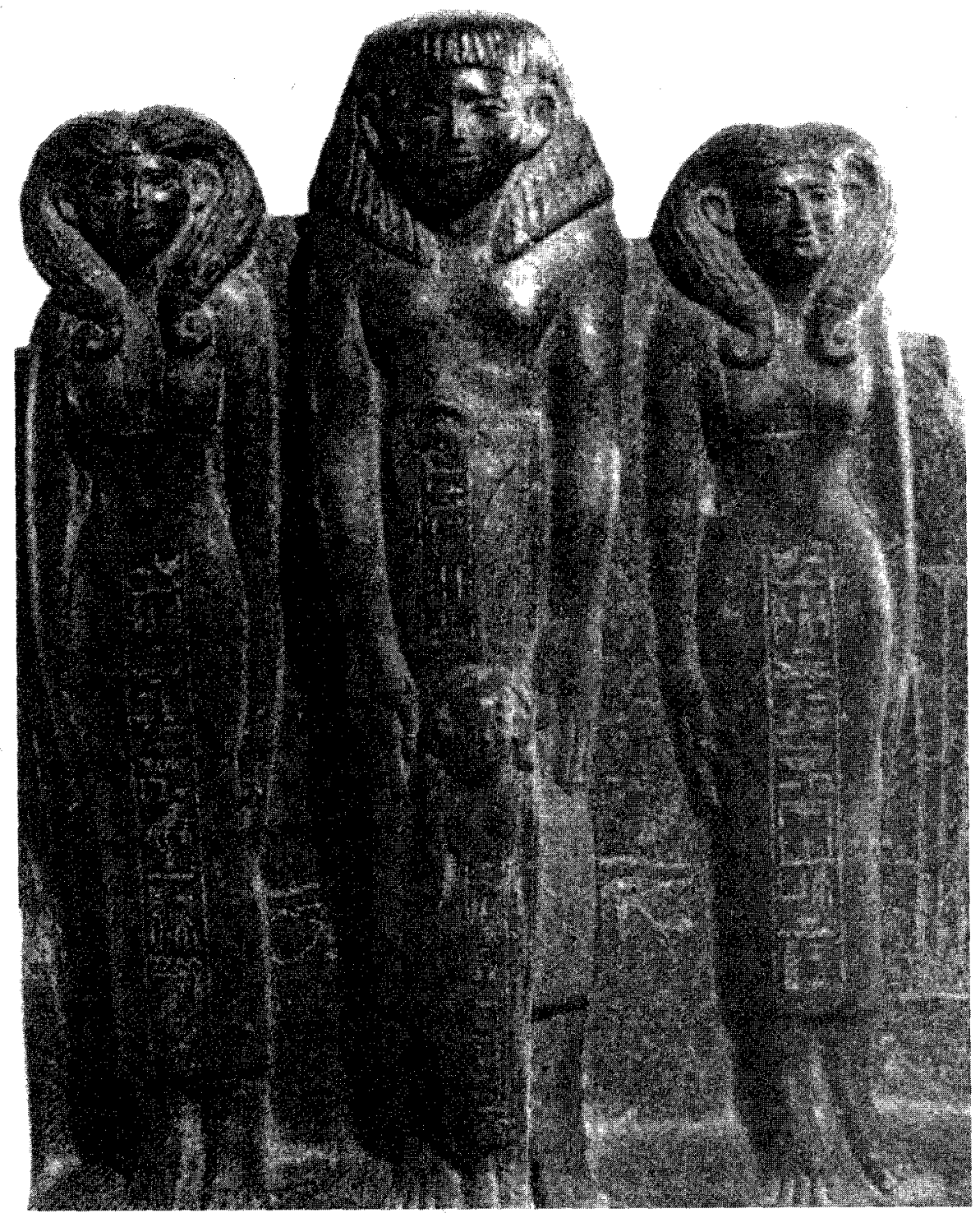

Ilustración 9. Grupo escultórico de Wekh-Hopte y su familia. Museo de Boston. 
De modo que, con los elementos de que disponemos, llegamos a la conclusión científica del matrimonio polígamo en base a los siguientes razonamientos:

a) Estaba legitimado no sólo a nivel real, para salvaguardar la «pureza de sangre", sino a nivel de la nobleza y del alto funcionariado, así como también del pueblo llano, siempre que pudiesen permitírselo económicamente, y nada permite pensar que precisamente ese pueblo llano tuviese impedimentos legales. No hay evidencias históricas a lo largo de la historia egipcia que avalen la tesis del matrimonio monógamo.

b) Es cierto que la costumbre monogámica fue el denominador común en el pueblo llano, en un buen porcentaje analfabeto y sin apenas recursos, formado mayoritariamente por campesinado, cuya prestación laboral estaba encaminada, al Horus, a los templos y al alto funcionariado, por lo que sus recursos económicos eran escasos. Y esa escasez, es decir por imperativo exclusivamente económico, era la única razón de la frecuente monogamia. Aquellos que lograban elevarse de «status» social, a través de las prestaciones militares, o por ser artistas y escultores que adquirían renombre, o determinados sacerdotes, les posibilitaba económicamente mantener más de una esposa, si ese era su deseo. No hubo por tanto impedimentos legales ni religiosos de ningún orden, y sí exclusivamente económicos.

c) Hasta el presente no nos ha llegado la más leve evidencia de leyes, decretos, usos o costumbres, prohibiendo taxativamente la poligamia, sino todo lo contrario, valorando los indicios que hasta hoy hemos recogido.

Si el matrimonio era una cuestión privada, concerniente exclusivamente a los cónyuges, donde la ley no entraba, sino «a posteriori», y sólo para la protección económica de sus crisis, no hay razón alguna para pensar que la monogamia se encontrara entronizada y la poligamia -excepción real- legalmente proscrita. No habiendo evidencias documentales no se puede apoyar científicamente el matrimonio monógamo como el único modelo legítimo.

Muchos historiadores se han apoyado fundamentalmente en Heródoto que cuando visitó Egipto dijo que era costumbre tener una sola esposa. Por el contrario Diodoro, dice que mientras los sacerdotes casan con una sola mujer, el resto de los egipcios con cuantas quieren.

Esas contradicciones, entre historiadores griegos, uno del siglo v y otro del I a.C. nos hacen ver que hay que ser cautos con ese tipo de fuentes.

La teoría del matrimonio poligámico en las más diversas culturales antiguas debe ser admitida a la luz de las evidencias históricas. A modo de 
ejemplo vamos a dar un brevísimo repaso por la institución matrimonial en el período precolombino:

Como todos Vds. saben, del imperio maya sólo se conservan 3 códices en el mundo: El Codex Peresianus que está en París; el que se encuentra en Dresde, y el Códice Trocortesiano que se encuentra en el Museo Arqueológico de Madrid. Eso y las ruinas es todo el soporte original y material que tenemos de esta cultura en época precolombina. Pero con eso y las referencias posteriores, cruzándolas, los historiadores del derecho antiguo sabemos que en la civilización maya, la familia se asentaba bajo el respeto a un antepasado común. $Y$ los padres del novio buscaban esposa en el mismo pueblo, entre vecinos pero no entre parientes, a través de acuerdos familiares, después del intercambio de regalos que el padre del novio hacía a su futuro consuegro. Tras la boda, el marido se trasladaba a casa de su suegro, a quien ayudaba en las labores de la tierra por un período de $5 \circ 6$ años. Durante ese tiempo la esposa, con el beneplácito de su madre, "daba de comer" a su marido. No otra cosa que el reconocimiento fáctico de la unión matrimonial, significaba este «acto de manutención». El divorcio consistía en la acción de abandonar el marido la casa de su suegro.

Las causas de divorcio eran tasadas y tomaban la forma del repudio para el caso concreto de la mujer, cuando se había producido un adulterio. Crimen que estaba penado con la muerte por lapidación, después de haber visto la causa en un juicio, y cuya pena, como en el caso de la cultura azteca, consistía en dejar caer sobre la cabeza del ofensor de la honra marital, una gran piedra, como se ve (ilustración n.10) en esta viñeta de «La Historia general de las cosas de la Nueva España», escrita por Fray Bernardino de Sahagún, y que se conserva en la biblioteca medicea-laurenziana de Florencia, y uno de cuyos facsímiles, se encuentra en mi biblioteca.

El libro se comenzó a escribir en 1550, en el convento de Santa Cruz de Tlateloco, México, en castellano y también en lengua «náhuat|».

Volviendo a los mayas, la poligamia estaba admitida por sus leyes y dependía exclusivamente, como entre los egipcios, de la capacidad económica del marido.

Entre las tribus «quichés» guatemaltecas, ocurría los mismo. Su concepto matrimonial era civil. Se podía contraer a partir de la pubertad. El desplazamiento del marido a casa del suegro era idéntico. No había ceremonias religiosas y la poligamia estaba admitida, siempre que el marido se obligara a la manutención de las esposas e hijos. 


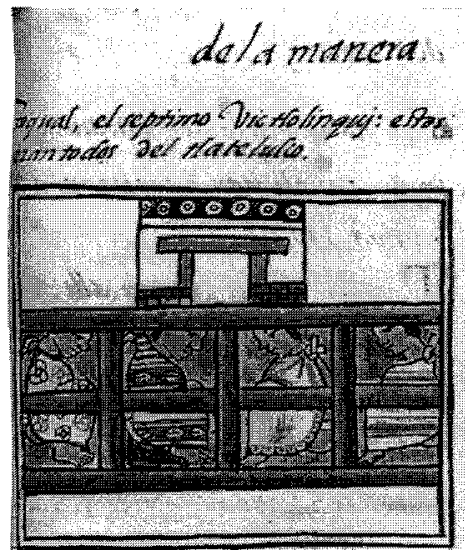

r. Dazzapbo tzzaco. Audi inta para ligento noblc.

Ot Acrowh. eneh 1

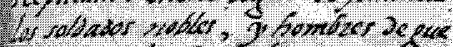

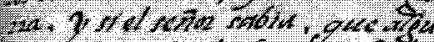
20 tells, ayjo heoss affern Jekro

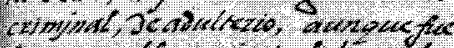

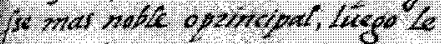

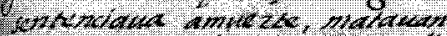

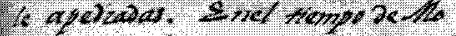

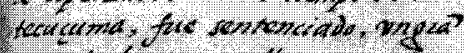

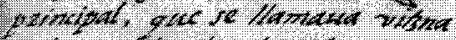

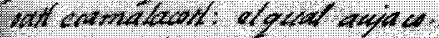

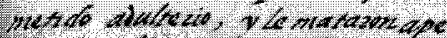

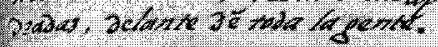

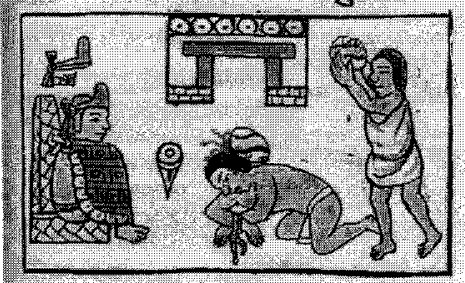

Ae tar rasas vales.

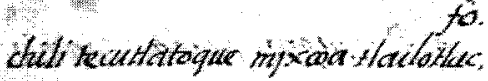
tece nostamadtit, Hacicticulicat, iz slaca mixcoutlailothac, bmaca, to qual, victlolingqu, thatitutca in

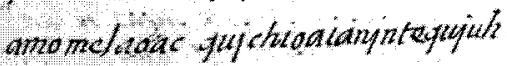

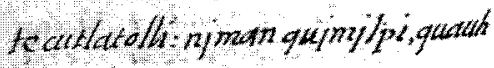
atco quintlah, quitsacutiaque, quin mict:

a Inj ci parrapho: ma miton motatoloian, $m$ wnann attea inkia caom, loom mpipilh.

Tecpilcalli, uncan atca, bnam tecponowia mpipilts, riacahoum oqucht, miducmoting, intlatod if mithaca itlaquimadititi pilli. mmanel cened tiacopilli fiaculuh milatetefin $x$ in, miman quithtsont tequilia, mjcteixpan tetopacho Lo totica migug motecuauma itloto cati, ceticrats Hacopilli itoia vith

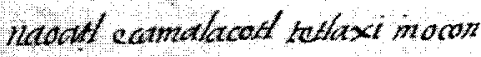
teixpauigue ixp, mn motecucumea, njmaniqujoallotsontequili, inje teixpom tetepachaloc.

Ilustración 10. Viñeta del Libro: "La Historia general de las cosas de la Nueva España». 
En cuanto a los impedimento matrimoniales, mientras el hombre podía casarse con su hermana uterina no podía hacerlo con su hermana de padre, pero si de madre. Si podía hacerlo con sus cuñadas y con su madrastra, pero no con aquellas mujeres que procediesen del parentesco paterno, es decir, tias o primas de la rama paterna.

Como Vds. saben, existen aún costumbres que parecen provenir de la época prehispánica. Que otra cosa si no, es el requiebro en los lavaderos, la rotura del cántaro de barro como «modus» de oficializar el noviazgo, la subordinación de la virginidad de la novia a la validez matrimonial, constatada por medio de la "sábana de la desfloración", como prueba y testimonio irrefutable de la virginidad.

¿Se dan cuenta Vds., de la pervivencia de este rito a través de la Alta Edad Media española, como una costumbre procedente del derecho germánico, en su institución de la "morgengabe» o "donación de la mañana", como premio otorgado por el marido a la mujer que había conservado su virginidad para el matrimonio?

¿Ven, cómo instituciones jurídicas, como es la importantísima del matrimonio, plantean similares comportamientos humanos frente a ellas, y cómo los egipcios ya las habían constituído como figuras jurídicas plenamente formadas y protegidas por el derecho?

Por último nos surge la pregunta de si en el matrimonio egipcio existía una igualdad conyugal o se daba una preponderancia marital.

Veámoslo a la luz de nuestros conocimientos actuales:

Lo primero que debemos tener presente en el período de tiempo que estamos estudiando es si en Egipto, como en el resto de otros pueblos que puedan estudiarse, la preponderancia marital, o del marido fue una tónica general.

Además de lo dicho con anterioridad, sólo hay que observar los diversos grupos escultóricos para distinguir dos tipos de «modus» matrimonial:

El oficial, cual es el de la escultórica representando faraones con sus esposas en menor tamaño, como es el caso de Usimaré (Ramsés II), en la XIX dinastía (ilustración n.11), o el más frecuente, en igual tamaño, como es el de Micerino, ya conocido por todos nosotros, donde su estatuaria se vé al mismo nivel, entre ambos esposos.

Veamos el gigantesco grupo escultórico que aparece a nuestros ojos (ilustración $n .12$ ), referido a Amenofis III y su esposa, la reina Tii, colosales estatuas provenientes del templo funerario real, al oeste de Tebas, y que hoy se pueden contemplar en la primera planta del Museo de El Cairo. 


\section{El derecho en el Egipto faraónico}

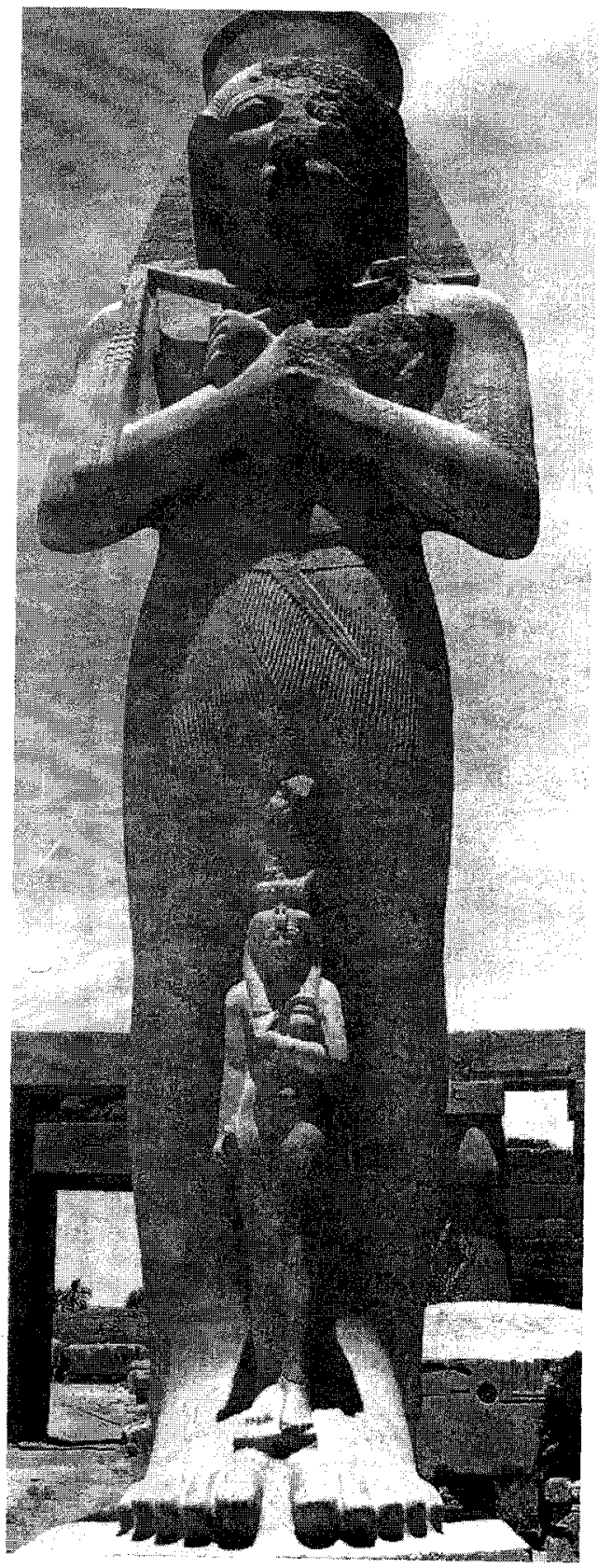

Justración 11. Estatua colosal de Ramsés II y su esposa. 


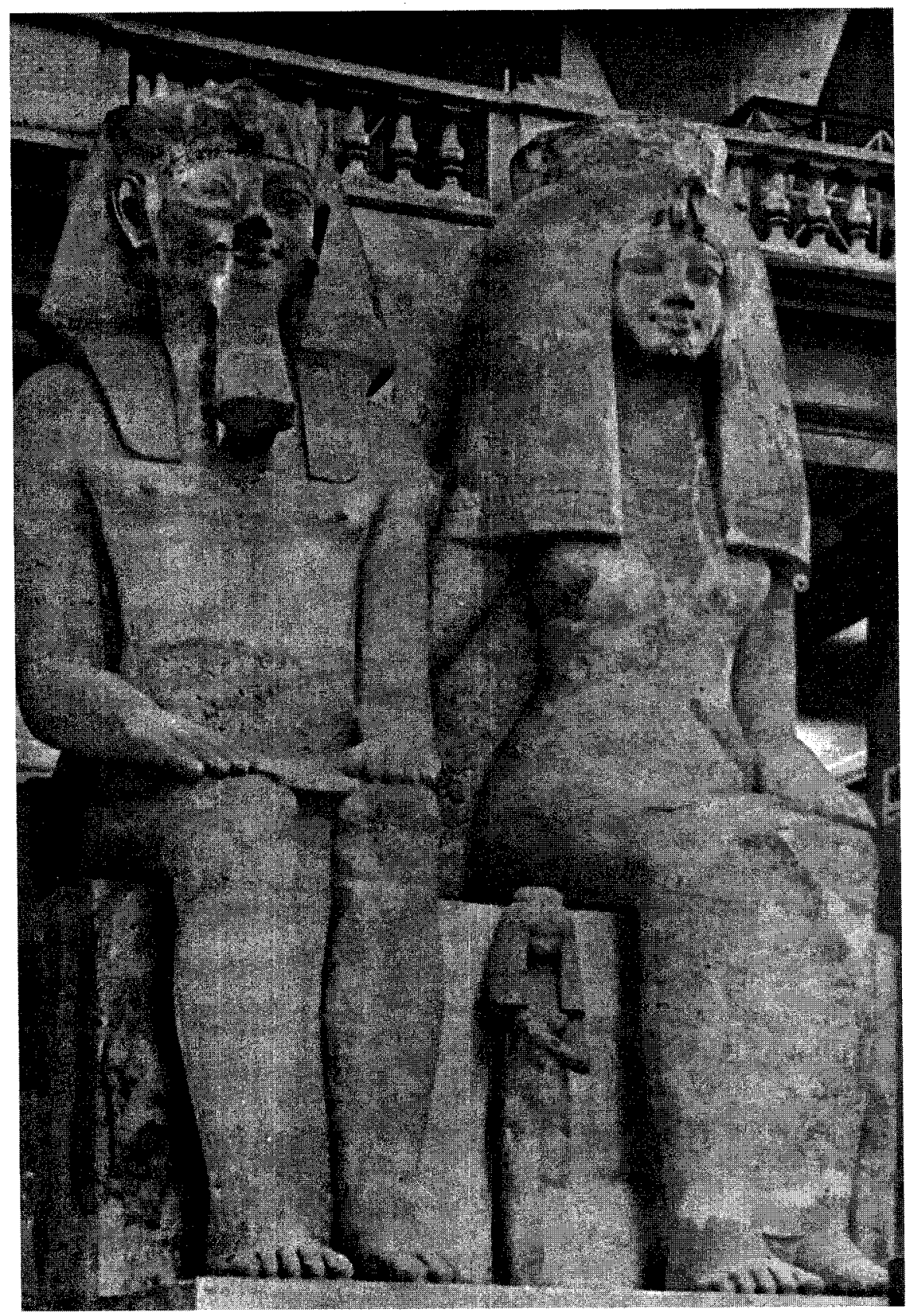

Ilustración 12. Amenofis III y su esposa. 
Obsérvese (ilustración n.ำ 13) el grupo de piedra caliza descubierta en Gizeh, datada a finales de la V dinastía, que hoy se encuentra en el Metropolitan Museum de Nueva York, representando al funcionario Memy Sabu y su esposa que rodea su talle, mientras él protege el seno izq. con su mano, dando la sensación de un matrimonio que ha querido dar a la posteridad una sensación de perenne felicidad matrimonial.

O el caso de Akhenaton y Nefertiti (ilustración n. 14 ), sujetos por sus manos demostrando su felicidad ante todos. Lo cual no quita para que después se produjese un divorcio matrimonial.

Aquí podemos observar (ilustración n.15) al enano Seneb y su esposa Sentiotes, de la VI dinastía, con sus hijos, niño y niña. Se trata de una caliza pintada de $33 \mathrm{~cm}$. procedente de su tumba, al oeste de la pirámide de Jufru y que se puede ver en el Museo de El Cairo.

Obsérvese como el artista ha resuelto magníficamente la altura de Seneb, colocando en el lugar de sus piernas, a los niños, con el gesto convencional de chuparse el dedo. Al niño se le aprecia, además, el mechón de pelo en el lado derecho de la cabeza y que se conocía como «rizo de Horus».

Como podrán comprobar Vds. la aparante felicidad familiar y matrimonial del antiguo Egipto, descrito en su estatuaria, nos podría llevar todo un año académico de observaciones y explicaciones, pero a «grosso modo» ya podemos darnos cuenta que la importancia de la mujer como esposa y, por tanto, su capacidad jurídica, excepto momentos muy puntuales de la historia, parece estar acreditado que fue plena, es decir, que la mujer tuvo un «status» jurídico similar al del hombre, si no exactamente idéntico.

Documentalmente hay constancia de la plena capacidad jurídica de obrar de la mujer, si nos fundamos en el papiro "Brooklyn 35/1466" donde se plantea la demanda de una mujer casada, contra su padre, disfrutando de una capacidad legal e independiente de su esposo, cuando defendiendo sus particulares intereses dice en el juicio: «Mi padre ha cometido una irregularidad. Posee objetos que me pertenecen por habérmelos dado mi marido. Pero mi padre se los ha entregado a su segunda esposa Senebtisi. Yo quiero obtener la restitución de lo que es mío".

No obstante lo anterior nos surge las dudas de si esa capacidad de obrar de la mujer era «omnium rerum» y «erga omnes», es decir para todas las cosas y frente a todo, o bien se encontraba restringida a determinados actos o bienes, necesitando para el resto de sus actos el cumplimiento de determinados requisitos jurídicos. Realmente no lo sabemos, pero parece estar claro que la mujer egipcia no necesitó, como la griega, de un «kyrios», o tutor de por vida, a través de su padre, hermanos, mari- 


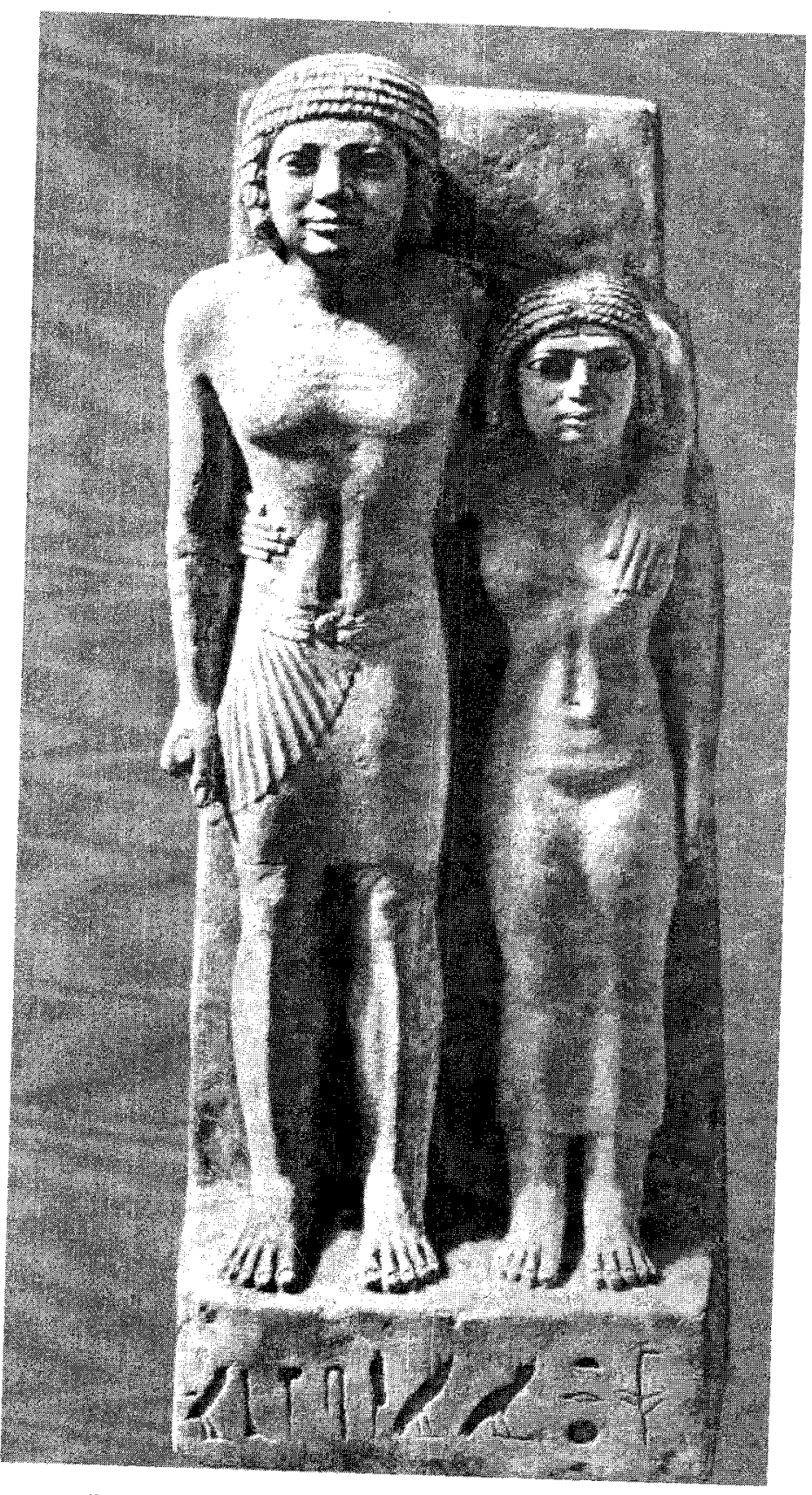

Mustración 13. El funcionario Memy Sabu y su esposa. 


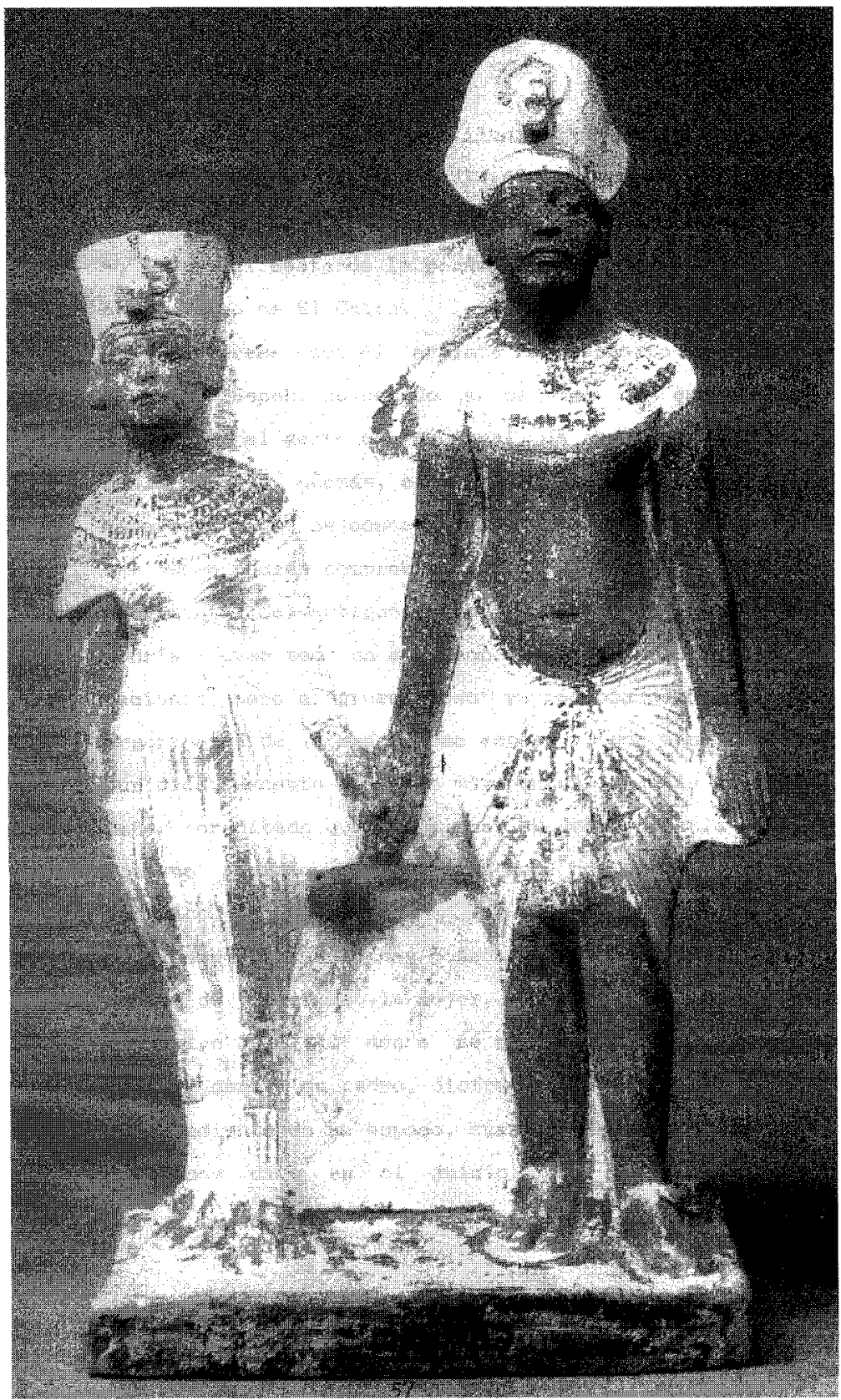

Ilustración 14. Akhenaton y Nefertiti. 


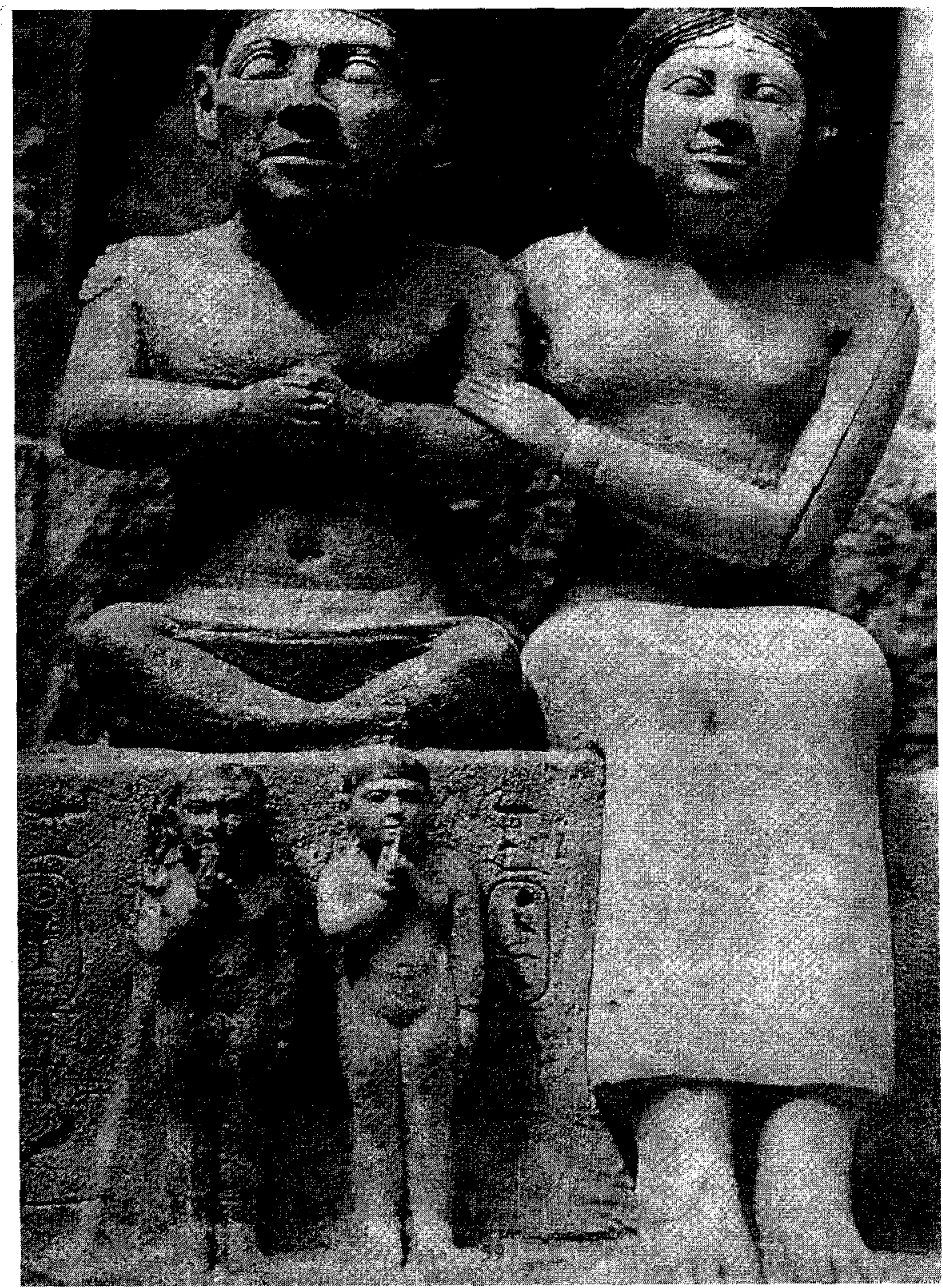

Justración 15. El enano Seneb y su familia. 
dos o hijos, sino que realizó actos con plena eficacia jurídica, según tenemos constancia. Otra cuestión es que, mayoritariamente, como ocurre hoy día en nuestra sociedad moderna, la mujer delegue multitud de cuestiones en manos de su marido, sin que eso signifique que legalmente ella se encuentre incapacitada para realizarlos.

\section{b) La teoría de la sedimentación - arrastre sedimentación-}

Viene a ser esto un «modus operandi» de cómo diversas instituciones jurídicas egipcias se fueron transmitiendo y quedaron como un poso o sedimento en las culturas griega y romana, a través de vectores histórico-geográficos, como Creta o Fenicia, entre otros.

Hoy en día es ya científicamente incontestable la preponderante influencia egipcia sobre las culturas minoica, griega y romana. Desde los criticados trabajos científicos de Revillout, a principios de este siglo, hasta las últimas certezas de Martin, Iniesta y Diop, entre otros a los que me sumo, y el reconocimiento del Coloquio de la UNESCO, en El Cairo, voy a demostrar que, en el campo jurídico el Egipto faraónico influyó, a manera de ósmosis, sobre la cultura occidental.

Vectores importantes fueron las rutas comerciales, terrestres y marítimas, y las conquistas militares. Los símbolos y objetos religiosos y de la vida cotidiana, han sido hallados en toda la costa mediterránea, incluso hasta las Islas Baleares, en España.

La influencia egipcia se expandió a través de dos frentes: el intercambio cultural y comercial y la conquista bélica, y de 3 vectores: de sur a norte, es decir, de Nubia primero y Tebas después, en el Alto Egipto, al Delta, en el Bajo Egipto, Pi-Ramsés, Bubastis, Buto. Estos vectores se irradiaron: 1) a la Costa Oriental; 2) a Creta y Chipre, y 3) a la Hélade.

De tal suerte que, a través de relaciones culturales, rutas comerciales y conquistas guerreras, su cultura, su sistema social, sus dioses, su ciencia y sus técnicas, se van "sedimentando" a través de la ósmosis e intercambio de «modus» a veces imperceptibles.

Una vez "sedimentada", osmotizada, mezclada, esa cuitura y esas instituciones, a través de esos paises, es decir Creta, Chipre, Grecia y, por último Roma, a modo de «parásitos", producen un fenómeno de «arrastre» de la cultura egipcia y de sus instituciones jurídicas. Fenómeno de «arrastre» que, a su vez, quedará «sedimentalizado" en aquellos pueblos y culturas sobre los que Creta, Grecia y Roma, a su vez, influyen. Así, por este fenómeno de «carambola», o caída del objeto golpeado que a su vez golpea y 
hacer caer al siguiente, se produce el fenómeno o teoría que he dado en llamar «Sedimentación - arrastre- sedimentación.

Sólo, y a modo de acercamiento, comentaremos algunos ejemplos:

Entre los sabios griegos, de Tales de Mileto, dice Pánfilo que había aprendido la geometría de sus maestros los sacerdotes egipcios, y de ellos sacó su famoso teorema. Diógenes nos dice que Pitágoras de Samos, fue recomendado al faraón Amasis por el tirano Polícrates, y allí aprendió la lengua egipcia y la doctrina de la transmigración del alma, que luego adoptaron los griegos. Eratóstenes, y su famosa "criba», fue aprendida por éste en el valle del Nilo. Plutarco, en su vida de Solón, nos acerca a las leyes que éste trajo de Egipto.

La concepción homérica del hombre y del «más allá», es totalmente egipcia, porque para Homero el hombre es la reunión del cuerpo, el hálito de vida, y el alma. Como saben Vds., para los egipcios el hombre estaba formado por el cuerpo o «kht» (jet); el hálito vital o «k3» (ka), y un alma individual o «b3» (ba). Además, para Homero el alma se encuentra representada por un pájaro, idéntico a como se representaba el «Ba» por los egipcios, muchos siglos antes. Como se vé la identidad es muy llamativa, y reparen Vds. que estas concepciones religiosas egipcias fueron expresadas muchos siglos antes. Por simple cronología, ¿quién ha influido sobre quién?

La nómina podría ser tan amplia que nos llevaría un excesivo tiempo.

En Roma, el derecho constantineo en materia de obligaciones, de impuestos, de administración de la tierra, en la administración pública, en la organización de oficios, cofradías y colegios, y en la autentificación de actos jurídicos, se inspira en el derecho egipcio faraónico, precisamente a través de leyes de la época ptolemaica. Más tarde la obra legislativa y recopiladora de Justiniano, es decir el llamado derecho justinianeo, es posible a través de la escuela jurídica de la ciudad fenicia de Berito, donde se había compuesto el Código Gregoriano del año 292 d.C.

De modo que la difusión de la cultura egipcia lleva consecuentemente a la difusión de su cultura jurídica, y sus instituciones, produciéndose una sutil conquista donde las «mores» o costumbres atraviesan imperceptiblemente las barreras geográficas.

Así pues, nuestro derecho es, por ahora, el último escalón de una serie de hitos jurídicos que naciendo en Sumer y en Egipto, han ido conformando el mundo del derecho occidental, tal y como lo conocemos y aplicamos, con mutuas influencias, impregnando de particularismos, pero en el fondo emergiendo las instituciones egipcias a poco que nos preocupemos de inquirir, más allá del derecho romano y de su particular e interesada historia. 